\title{
Structure-Based Discovery of Novel and Selective 5-Hydroxytryptamine 2B Receptor Antagonists for the Treatment of Irritable Bowel Syndrome
}

\author{
Yu Zhou, ${ }^{\dagger,+, \# ~ J i n g ~ M a, ~}{ }^{\S, \#}$ Xingyu Lin, ${ }^{\dagger}$ Xi-Ping Huang, $"$ Kaichun Wu, ${ }^{* \S}$ and Niu Huang ${ }^{*}{ }^{\dagger}$ \\ ${ }^{\dagger}$ National Institute of Biological Sciences, Beijing, No. 7 Science Park Road, Zhongguancun Life Science Park, Beijing 102206, China \\ ${ }^{*}$ Department of Pharmacology and Pharmaceutical Sciences, School of Medicine, Tsinghua University, Beijing 100084, China \\ ${ }^{\S}$ State Key Laboratory of Cancer Biology and Xijing Hospital of Digestive Diseases, Fourth Military Medical University, 127 West \\ Changle Road, Xi'an, Shaanxi Province 710032, China \\ "Department of Pharmacology, The National Institute of Mental Health Psychoactive Drug Screening Program (NIMH PDSP), The \\ University of North Carolina, Chapel Hill, North Carolina 27759, United States
}
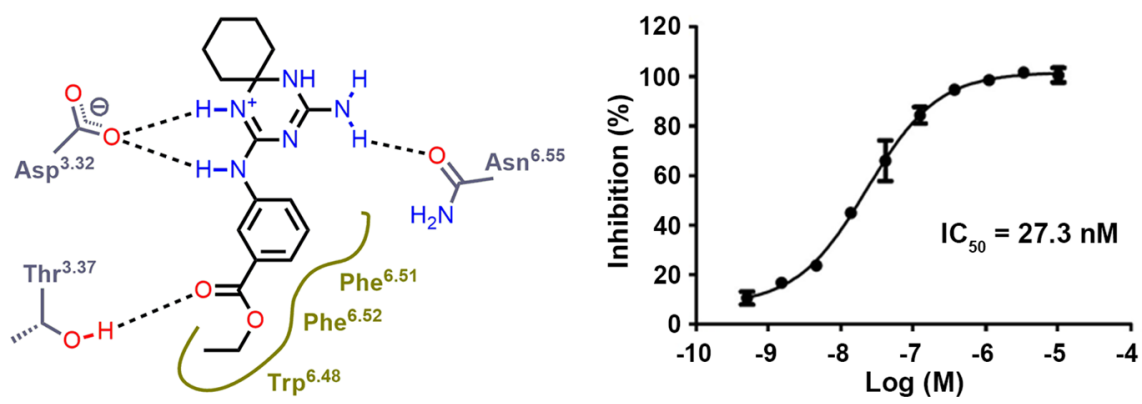

ABSTRACT: Here we employed structure-based ligand discovery techniques to explore a recently determined crystal structure of the 5-hydroxytryptamine $2 \mathrm{~B}\left(5-\mathrm{HT}_{2 \mathrm{~B}}\right)$ receptor. Ten compounds containing a novel chemical scaffold were identified; among them, seven molecules were active in cellular function assays with the most potent one exhibiting an $\mathrm{IC}_{50}$ value of $27.3 \mathrm{nM}$. We then systematically probed the binding characteristics of this scaffold by designing, synthesizing, and testing a series of structural modifications. The structure-activity relationship studies strongly support our predicted binding model. The binding profiling across a panel of $115-\mathrm{HT}$ receptors indicated that these compounds are highly selective for the 5- $\mathrm{HT}_{2 \mathrm{~B}}$ receptor. Oral administration of compound $15(30 \mathrm{mg} / \mathrm{kg})$ produced significant attenuation of visceral hypersensitivity in a rat model of irritable bowel syndrome (IBS). We expect this novel scaffold will serve as the foundation for the development of 5-HT $\mathrm{H}_{2 \mathrm{~B}}$ antagonists for the treatment of IBS.

\section{INTRODUCTION}

G-protein coupled receptors (GPCRs) represent the most prominent pharmaceutical targets in drug discovery, and over $40 \%$ of marketed drugs act through them. ${ }^{1}$ GPCR drugs have typically been developed based on the traditional medicinal chemistry approach, which has restricted the diversity of the chemical scaffolds considered as candidate drugs. Recent progress in the determination of GPCR structures has opened up great opportunities for structure-based discovery efforts seeking novel GPCR ligands. Docking screens against these crystal structures have been successfully applied in identification of novel potent ligands. ${ }^{2-8}$

The $5-\mathrm{HT}_{2 \mathrm{~B}}$ receptor is one of the recently determined GPCR structures. ${ }^{9,10}$ It belongs to $5-\mathrm{HT}_{2}$ receptor family, which includes three subtypes: $5-\mathrm{HT}_{2 \mathrm{~A}}, 5-\mathrm{HT}_{2 \mathrm{~B}}$, and $5-\mathrm{HT}_{2 \mathrm{C}}$. Although both the $5-\mathrm{HT}_{2 \mathrm{~A}}$ and $5 \mathrm{HT}_{2 \mathrm{C}}$ receptors have been widely studied as therapeutic targets, drug discovery efforts focused on the $5-\mathrm{HT}_{2 \mathrm{~B}}$ receptor have been relatively limited. 5-
$\mathrm{HT}_{2 \mathrm{~B}}$ agonism has been regarded as a side effect for drug molecules, as its activation is related to cardiac hypertrophy and pulmonary hypertension. ${ }^{11,12}$ More recent studies have focused on the possible application of $5-\mathrm{HT}_{2 \mathrm{~B}}$ antagonists. ${ }^{13}$ Several compounds have been advanced to clinical trials in several disease areas, including migraine disorder, ${ }^{14,15}$ irritable bowel syndrome (IBS), ${ }^{16,17}$ and pulmonary arterial hypertension (PAH). ${ }^{18,19}$

IBS is a common functional gastrointestinal (GI) disorder worldwide that is characterized by abdominal pain and alterations in bowel habits. Despite these impacts, the pathogenic mechanism of this disease remains incompletely understood and seems to be multifactorial. ${ }^{20}$ Visceral hypersensitivity is now widely accepted as one of the core characteristics, and this probably plays a major role in the 
A<smiles>CN(C)CCCc1cccc2oc3ccccc3c12</smiles>

doxepin

$$
\begin{aligned}
& 5-\mathrm{HT}_{2 \mathrm{~B}}: \\
& \mathrm{K}_{\mathrm{i}}=56 \mathrm{nM}, \\
& \mathrm{IC}_{50}=89 \mathrm{nM} .
\end{aligned}
$$

B

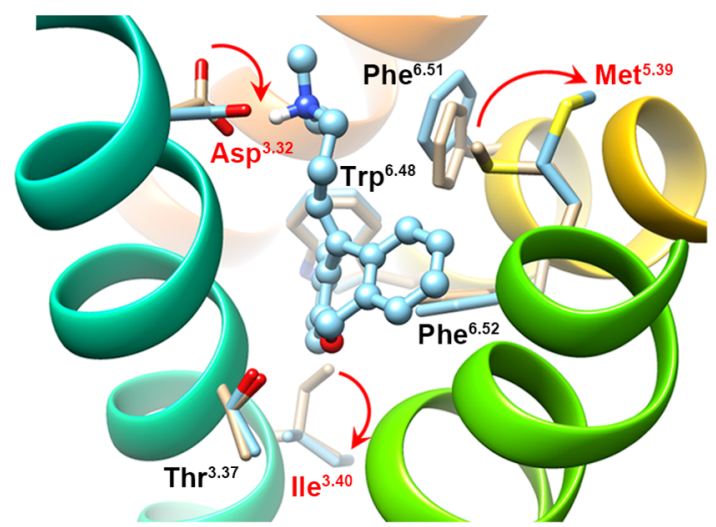

D

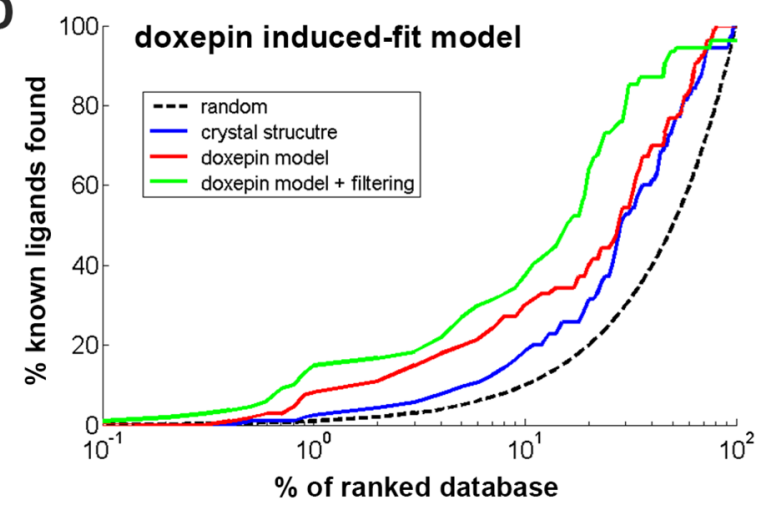

Figure 1. Binding site refinement of the 5- $\mathrm{HT}_{2 \mathrm{~B}}$ crystal structure. (A) Chemical structures and biological activities of doxepin and carvedilol. (B) Comparison of the doxepin induced-fit model (cyan) with the 5- $\mathrm{HT}_{2 \mathrm{~B}}$ crystal structure (tan, PDB ID: 4IB4). (C) Solvent property analysis of the 5$\mathrm{HT}_{2 \mathrm{~B}}$ binding pocket. Predicted water clusters are shown as spheres. The volume of spheres represents their occupancy in the simulation, and the color represents their free energy. Blue indicates that the water molecule is energy favorable, while red indicates it is energy unfavorable. (D) The enrichment profile of the doxepin induced-fit model. The percentage of ligands found ( $y$-axis) plotted as a function of the percentage of the docking ranked database ( $x$-axis in logarithmic scale).

development of disease symptoms. ${ }^{21}$ Currently, there is no effective cure for IBS. Traditional management has mainly focused on the relief of symptoms. The efficacy of these management approaches has been limited, and the side effects of various drugs used to relieve symptoms have been problematic. For example, the $5-\mathrm{HT}_{3}$ antagonist alosetron was approved by the US FDA in 2000 and is used to treat the diarrhea-predominate form of IBS. $^{22}$ Unfortunately, severe adverse GI reactions were reported soon after its introduction to the market. In 2015, the US FDA approved two new drugs for the diarrhea-predominate form of IBS. The effects of rifaximin, an antibiobic derived from refampin, are thought to be related to changes in the bacterial content in the GI tract. Eluxadoline, a mixed opioid receptor ligand, acts on the nervous system to reduce bowel contractions. However, the safety of these two drugs is still of great concern given reported side effects that include constipation, nausea, spasm, and increased alanine aminotransferase levels. ${ }^{23}$

Recent studies have strongly suggested that the $5-\mathrm{HT}_{2 \mathrm{~B}}$ receptor plays an important role in the pathogenesis of IBS; it is therefore a promising target for the development of novel therapies. The 5- $\mathrm{HT}_{2 \mathrm{~B}}$ receptor is widely expressed throughout the human intestinal tract. ${ }^{13}$ It may function in regulating the contraction of smooth muscle to mediate GI motility and visceral perception. The activation of the $5-\mathrm{HT}_{2 \mathrm{~B}}$ receptor was shown to increase the proliferation of interstitial cells of Cajal through protein kinase $\mathrm{C} \gamma$, a process that may lead to motility disorder and visceral hypersensitivity in the colon. ${ }^{24}$ In addition, increased $5-\mathrm{HT}_{2 \mathrm{~B}}$ receptor expression has been reported for rat models of diarrhea-predominant IBS. $^{25}$ Selective antagonism of the $5-\mathrm{HT}_{2 \mathrm{~B}}$ receptor in IBS rats has been shown to produce significant attenuation of visceral hypersensitivity and improvement with defecation. ${ }^{26-29}$

Currently, only a few selective antagonists of the $5-\mathrm{HT}_{2 \mathrm{~B}}$ receptor have been reported, due to the high degree of homology with its closely related protein family members. ${ }^{30}$ Therefore, the discovery of novel and selective $5-\mathrm{HT}_{2 \mathrm{~B}}$ antagonists would be of great interest to further explore the physiological function and therapeutic application of the 5$\mathrm{HT}_{2 \mathrm{~B}}$ receptor. In the present study, we used structure-based virtual screening to explore the opportunity presented by a recently published crystal structure of the $5-\mathrm{HT}_{2 \mathrm{~B}}$ receptor to identify novel antagonists against this protein. One class of compounds with a novel structural scaffold was enriched among the top of the scoring list. Compounds from this class were validated in cellular functional assays and binding profiling assays. We further performed structure-activity relationship (SAR) studies to assess the predicted binding pose of this scaffold, which led to the selection of a promising candidate with high binding affinity and high selectivity for the $5-\mathrm{HT}_{2 \mathrm{~B}}$ receptor. In vivo studies of this drug candidate suggested that this class of $5-\mathrm{HT}_{2 \mathrm{~B}}$ antagonists can serve as a promising starting point for the development of new drugs to treat IBS. 


\section{RESULTS}

Binding-Site Refinement of the $5-\mathrm{HT}_{2 \mathrm{~B}}$ Crystal Structure. GPCR undergoes conformational changes to accommodate different ligands, and these conformational changes are especially pronounced when making comparisons between agonist-bound structures and antagonist-bound structures. The only currently available $5-\mathrm{HT}_{2 \mathrm{~B}}$ crystal structure is bound with a biased agonist (ergotamine), and it has been suggested that this structure exhibits conformational characteristics of both the active and the inactive states (Figure S1A, Supporting Information). ${ }^{9}$ Compared with other inactive aminergic GPCR structures, the conserved anchor residue $\mathrm{Asp}^{3.32}$, which is critical for ligand binding, adopts a different orientation in the $5-\mathrm{HT}_{2 \mathrm{~B}}$ structure (Figure S1B). Accordingly, rigid-receptor docking against this conformation might be of limited utility in identifying efficacious antagonists. ${ }^{7}$ Thus, instead of docking to the crystal conformation directly, we deliberately modified the structure to incorporate the inducedfit effects associated with $5-\mathrm{HT}_{2 \mathrm{~B}}$ antagonists. ${ }^{31}$ To obtain a reliable induced-fit structural model, we selected two promiscuous GPCR ligands: doxepin and carvedilol (Figure $1 \mathrm{~A})$. Both of them exhibit potent $5-\mathrm{HT}_{2 \mathrm{~B}}$ antagonist activity; ${ }^{32}$ they also bind to other GPCRs and have corresponding crystal complex structures available (with histamine $\mathrm{H}_{1}$ and $\beta_{1^{-}}$ adrenergic receptors, respectively). ${ }^{33,34}$

Figure 1B illustrates the doxepin induced-fit model, in which doxepin maintains the dominant interactions that form in the histamine $\mathrm{H}_{1}$ receptor (Figure S2, Supporting Information). The amine moiety forms an anchor salt bridge with $\mathrm{Asp}^{3.32}$. The tricyclic rings of doxepin sit deeply in the hydrophobic binding pocket and are surrounded by the following highly conserved residues: $\mathrm{Ile}^{3.40}, \operatorname{Trp}^{6.48}, \mathrm{Phe}^{6.51}$, and $\mathrm{Phe}^{6.52}$. The oxygen atom of doxepin ( $\mathrm{E}$ isomer) forms a hydrogen bond with $\mathrm{Thr}^{3.37}$, which is consistent with that in the histamine $\mathrm{H}_{1}$-doxepin crystal complex structure. This result significantly bolstered our confidence about the properties of our induced-fit model. Compared with the initial crystal configuration, we found that three residues experience significant conformational changes in the doxepin induced-fit conformation. Asp $\mathrm{p}^{3.32}$ orientates toward the binding pocket, forming a salt bridge with the ligand, an orientation consistent with that of other inactive monoamine GPCRs. Yet both $\mathrm{Met}^{5.39}$ and $\mathrm{Ile}^{3.40}$ rotate away from the ligand, resulting in a larger binding pocket. Notably, the conformation of $\mathrm{Ile}^{3.40}$ is switched back to the inactive state as shown in other inactive aminergic GPCR structures. We observed similar (but less pronounced) conformational changes in the carvedilol induced-fit model (Figure S3A, Supporting Information).

We further analyzed the binding-site solvent properties of the $5-\mathrm{HT}_{2 \mathrm{~B}}$ receptor. The displacement of water molecules from the binding pocket is a key component of ligand binding. Here we calculated the thermodynamic properties of binding-site water molecules in the $5-\mathrm{HT}_{2 \mathrm{~B}}$ receptor using the Solvent Property Analysis (SPA) program. ${ }^{35}$ The predictions for occupancy and free energy of the binding-site waters enabled us to generally summarize the potential interaction patterns of $5-\mathrm{HT}_{2 \mathrm{~B}}$ ligands (Figure 1C). First, a cluster of highly energyfavorable waters surround the negatively charged residue Asp $^{3.32}$, the displacement of which would result in a large enthalpy penalty. Thus, a positively charged amine group is usually required here for the ligand to form a salt bridge interaction with $\mathrm{Asp}^{3.32}$ to compensate for the energy penalty.
Second, three less energy-favorable waters form hydrogen bond interactions with $\mathrm{Asn}^{6.55}$, implying a potential hydrogen bond interaction with the ligand in this position. We also identified a group of energy-unfavorable waters bound deeply within the binding pocket that were restricted by the aromatic rings of nearby residues. A nonpolar planar group here would generate significant potency from the entropy gain of the water displacement. The distribution of these binding-site waters represents the chemical composition of an ideal ligand. On the basis of the above analysis, we derived three structural filters for the screening of $5-\mathrm{HT}_{2 \mathrm{~B}}$ antagonists: (a) a salt bridge interaction must be formed between the positively charged amine group of the ligand and residue $\mathrm{Asp}^{3.32}$; (b) the region of unfavorable waters should be occupied by a hydrophobic group of the ligand (here we define the occupation as at least one carbon atom having a distance $<3 \AA$ from the oxygen atom of each water molecule); (c) considering the overall hydrophobic nature of the binding site, there should not be many polar atoms that do not form a hydrogen bond interaction. Thus, a ligand with three or more polar atoms buried in the pocket should form at least one hydrogen bond with receptor residues.

We next estimated the ability of our induced-fit models to enrich known antagonists of the $5-\mathrm{HT}_{2 \mathrm{~B}}$ receptor from a background of physicochemically similar, but structurally dissimilar, decoys. The derived structural filters were also applied. The docking results suggested that both of the induced-fit models provide better enrichment performance than does the original crystal structure; this was especially the case when the models were combined with structural filters (Figure $1 \mathrm{D}$ and Figure S3B). The EF1 values (enrichment factor at $1 \%$ of the ranked database) were $2.4,8.2$, and 5.8 for the crystal structure, the doxepin model, and the carvedilol model, respectively. Structural filtering further improved the results, yielding EF1 values of 4.6, 14.9, and 10.5, respectively. The doxepin induced-fit model combined with structural filtering exhibited the best performance. Thus, we finally selected the doxepin induced-fit model for use in further virtual screening efforts.

Identification of a Novel Scaffold in Prospective Virtual Screening. A structure-based hierarchical virtual screening strategy ${ }^{36,37}$ was applied to identify novel $5-\mathrm{HT}_{2 \mathrm{~B}}$ antagonists. To balance efficiency and accuracy, this protocol combines molecular docking-based high throughput screening and minimization-based MM-GB/SA rescoring (Figure 2). We initially docked our in-house compound library that contains 100413 diverse drug-like compounds. More than 300000 binding conformations were generated, and the 10000 topranked poses were further subjected to minimization-based MM-GB/SA refining and rescoring. We then saved the 1000 top-ranked nonredundant compounds for structural analysis; only 253 of the hits passed the structural filters. With the aim of identifying a novel $5-\mathrm{HT}_{2 \mathrm{~B}}$ ligand scaffold, we subjected these surviving molecules to the Similarity Ensemble Approach ${ }^{38}$ (SEA, http://sea.bkslab.org) server in an effort to avoid the selection of compounds that are structurally similar to known GPCR ligands. Finally, we obtained 169 molecules of interest (Table S1, Supporting Information). Among these, one scaffold in particular stood out, as ten molecules with this scaffold were enriched in the hit list, and all ten of these molecules adopted a similar binding mode (Figure 3A and Table S2, Supporting Information).

Cellular functional assays were performed to validate the antagonist activity of the ten selected molecules. Encouragingly, 


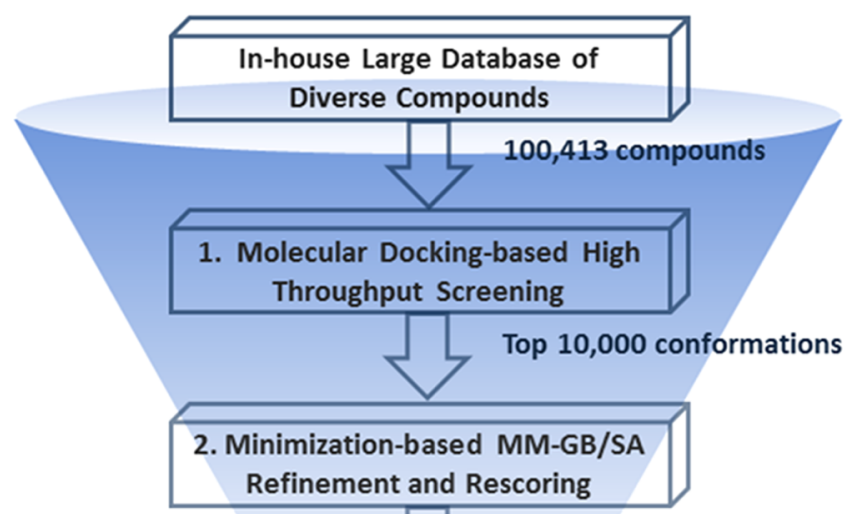

Top 1,000 compounds

\section{Structural Filters \& SEA Analysis}

169 compounds passed

10 with identified scaffold

Antagonist Activity Assay

Figure 2. Flowchart of the structure-based hierarchical virtual screening strategy.

seven compounds exhibited $>50 \%$ inhibition at a $10 \mu \mathrm{M}$ concentration and five of these seven exhibited $>50 \%$ inhibition at a $1 \mu \mathrm{M}$ concentration (Figure $3 \mathrm{~B}$ ), results that clearly suggested that a common mode of action was shared by this series of compounds. We further determined the doseresponse inhibition activity of these five compounds (Table S2). The most potent one, compound 9 (Figure 3C), exhibits an $\mathrm{IC}_{50}$ value of $27.3 \mathrm{nM}$ (Figure 3D).
Assessment of the Predicted Binding Mode. These compounds represent a novel class of $5-\mathrm{HT}_{2 \mathrm{~B}}$ antagonists. The triazine ring in trizazspiro is basic (with experimental $\mathrm{p} K_{\mathrm{a}}$ of $10-11) .{ }^{39}$ Thus, it is protonated in solution and forms the salt bridge interaction with conserved Asp $\mathrm{p}^{3.32}$ through $\mathrm{N}^{1}$ and the nitrogen atom on the 2 -amine group (Figure $4 \mathrm{~A}$ ). The nitrogen atom on the 4-amine group forms a hydrogen bond with residue Asn ${ }^{6.55}$. The saturated cyclohexene group is located in the entrance of the binding pocket and forms hydrophobic contacts with extracellular loop II (ECL II). The phenyl ring is deeply buried into the inner part of the hydrophobic pocket and is surrounded by the aromatic side chains of residues $\operatorname{Trp}^{6.48}$, Phe ${ }^{6.51}$, and $\mathrm{Phe}^{6.52}$. These interactions are quite consistent with the above solvent property analysis. Specifically, for compound 9, there is an additional hydrogen bond interaction with residue $\mathrm{Thr}^{3.37}$ that may further contribute to its strong binding. Compared with the crystal structure of 5$\mathrm{HT}_{2 \mathrm{~B}}$-ergotamine complex, our compounds occupy the orthosteric binding pocket, without completely overlapping with the biased agonist ergotamine binding site (Figure S4, Supporting Information).

On the basis of this predicted binding mode and potential chemical modifications, we next probed the binding characteristics by envisioning and testing a series of structural analogues (Table 1). To confirm the salt bridge interaction, we synthesized compound 11, in which a methyl group was added to the nitrogen atom on the 2-amine group. As we expected, this modification destabilized the salt bridge with residue $\mathrm{Asp}^{3.32}$ and led to a remarkable decrease in potency. Further, compound 12, with a cyclized $\mathrm{N}^{1}$ nitrogen atom, could not form the salt bridge interaction and lost all activity. Compounds 13 and 14 were designed to probe the hydrogen bond to residue Asn ${ }^{6.55}$. A single methyl group added on the nitrogen atom of 4-amine group preserves the hydrogen bond.
A<smiles>[R]c1ccc(NC2=NC(N)=NC(CC)(CC)C2)cc1</smiles>

Scaffold $(n=0,2$ or 3$)$

C<smiles>CCOC(=O)c1cccc(NC2=NC(N)=NC3(CCCCC3)N2)c1</smiles>

Compound 9
B

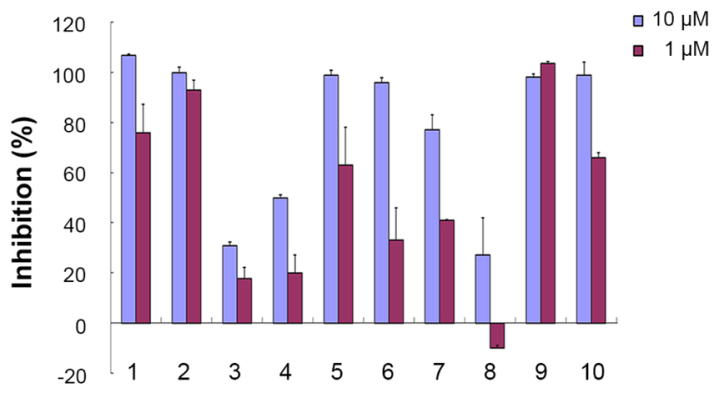

D

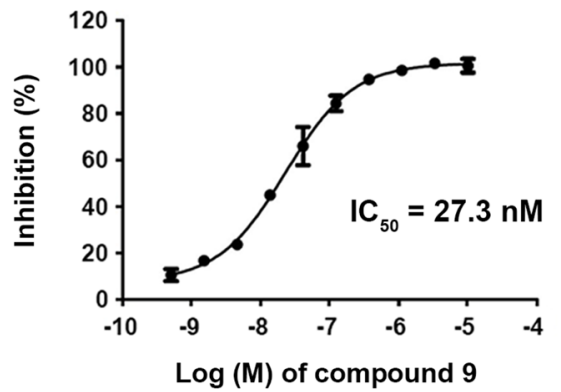

Figure 3. Experimental validation of the identified compounds. (A) Scaffold of the identified compounds. (B) Inhibitory activity on the 5-HT $2 \mathrm{~B}$ receptor at $10 \mu \mathrm{M}$ and $1 \mu \mathrm{M}$ concentrations. (C) Chemical structure of compound 9. (D) The dose-dependent inhibitory response curve of compound 9 on the $5-\mathrm{HT}_{2 \mathrm{~B}}$ receptor. 


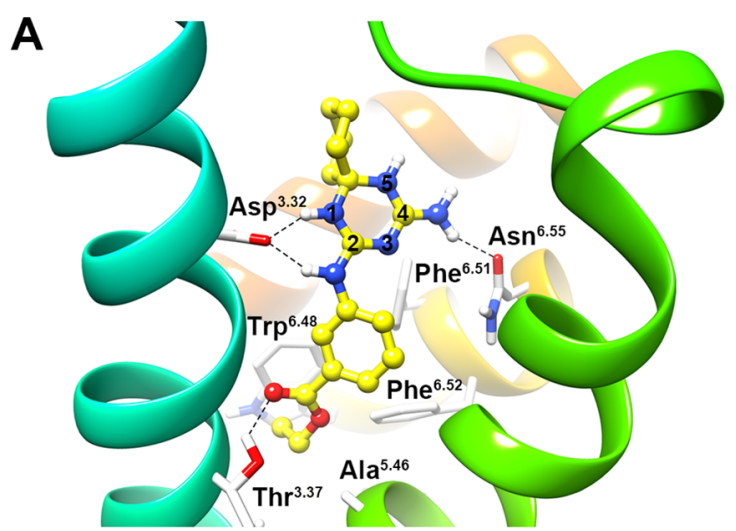

B

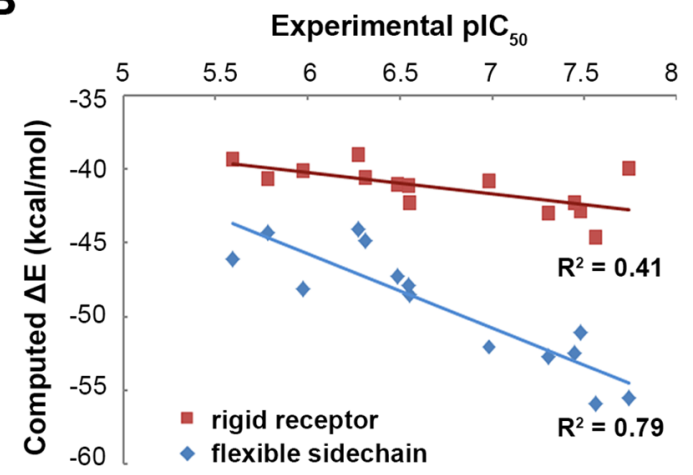

Figure 4. (A) Predicted binding mode of compound 9. (B) Correlation between the experimental $\mathrm{pIC}_{50}$ and the computed $\Delta E$ based on the predicted binding mode.

Therefore, compound 13 exhibited comparable inhibitory activity with compound 9 , with an $\mathrm{IC}_{50}$ value of $49.4 \mathrm{nM}$. However, the substitution of two methyl groups totally abolished the hydrogen bond interaction, resulting in a $>10$ fold decrease in the potency of compound 14. The saturated cyclohexane ring forms hydrophobic contacts with residues on ECL II. The effects of subtle variations to this region were also explored. Replacing the cyclohexane subunit with a smaller germinal dimethyl or saturated cyclopentane group yielded, respectively, 10-fold and 4-fold decreased potency (compounds $1,5,15$, and 16).

We then focused on the R-substituents on the phenyl group, which sits deeply in the hydrophobic binding pocket and makes extensive contacts with nearby residues. A series of structural analogues were tested (Table 2). Compound 17, without any modifications on the phenyl ring group, exhibited no inhibition of the $5-\mathrm{HT}_{2 \mathrm{~B}}$ receptor, indicating that the hydrophobic interaction in the binding pocket might be essential for the antagonist activity. The $\mathrm{R}^{2}$ position is restricted by the ligand itself or by nearby residues in the protein. Modifications on this site contribute little to binding. Thus, compound 18 and 19 yielded minimal increase in potency. The $\mathrm{R}^{3}$ position is buried deeply into the pocket, where bulky groups are tolerable. We surmised that nonpolar substitutions on this site would introduce favorable hydrophobic interactions. As expected, the potency was significantly enhanced by various monosubstitutions at the $\mathrm{R}^{3}$ position. For example, compounds 15 and 16, modified by a bromine atom or methoxy group, respectively, exhibited potent inhibition; the $\mathrm{IC}_{50}$ values for these two compounds were $33.4 \mathrm{nM}$ and $280 \mathrm{nM}$. Considering the hydrolytic lability of the ester group in compound 9, we also synthesized and tested its hydrolysis product, compound 20. However, no inhibitory activity was detected. This may be because the negatively charged group is unfavorable for binding in the hydrophobic pocket surrounded by aromatic rings, owing to a large desolvation penalty. This led us to synthesize compounds $\mathbf{2 1}$ and 22, with the replacement of the ester group with, respectively, a carbonyl group and an amide group to pursue improved stability; their $\mathrm{IC}_{50}$ values were $35.8 \mathrm{nM}$ and $104.0 \mathrm{nM}$. Compound 23, with an additional methyl group added to compound 9, exhibits a slightly stronger inhibition, with an $\mathrm{IC}_{50}$ value of $18.1 \mathrm{nM}$. Compounds 24 and 25, substituted with relatively bulky groups, exhibited no activity or very low activity, consistent with a narrow and deep cleft in this position in the receptor binding site (Figure S5, Supporting Information). As for the $\mathrm{R}^{4}$ position, the space is relatively small (Figure 4A). Only small substitutions such as methyl groups or a chlorine atom (compound 26 and 27) are tolerable. Larger groups here, such as that in compound 28, introduce steric clashes and diminish binding.

The above SAR results strongly support our predicted binding mode. On the basis of this binding mode, we further calculated the binding energies of 14 compounds with experimentally determined $\mathrm{IC}_{50}$ values, using the MM-GB/SA rescoring method. In our previous work, ${ }^{36}$ the target protein is usually kept rigid during the minimization process of the ligand-protein complex. Here we also attempted to include side-chain flexibility during the rescoring stage by simply minimizing side-chain conformations along with the ligand. ${ }^{40}$ There were good correlations between the experimental $\mathrm{pIC}_{50}$ and the computed $\Delta E$ (Figure $4 \mathrm{~B}$ ). This further supports the assertion that our predicted binding mode is reasonable. Of particular note was the improved correlation $\left(R^{2}=0.79\right)$ between the experimental $\mathrm{pIC}_{50}$ and the computed $\Delta E$ that resulted from the flexible treatment of the side chains of the binding-site residues, emphasizing the importance of incorporating protein flexibility into ligand binding energy calculation.

Binding Selectivity over Other 5-HT Receptors. We performed binding profiling tests for five compounds on a panel of $115-\mathrm{HT}$ receptors. The results suggested that this class of compounds are relatively specific to the $5-\mathrm{HT}_{2 \mathrm{~B}}$ receptor (Table 3). They strongly bound to the $5-\mathrm{HT}_{2 \mathrm{~B}}$ receptor, with $K_{\mathrm{i}}$ values ranging from $6.2 \mathrm{nM}$ to $38.5 \mathrm{nM}$, and bound only weakly to the other six 5-HT receptors (5$\mathrm{HT}_{1 \mathrm{~A}}, 5-\mathrm{HT}_{1 \mathrm{~B}}, 5-\mathrm{HT}_{1 \mathrm{D}}, 5-\mathrm{HT}_{5}, 5-\mathrm{HT}_{6}$, and $5-\mathrm{HT}_{7}$ ); they did not bind to $5-\mathrm{HT}_{1 \mathrm{E}}$ and $5 \mathrm{HT}_{3}$. Even for $5-\mathrm{HT}_{2 \mathrm{~A}}$ and $5-\mathrm{HT}_{2 \mathrm{C}}$, which are the two most highly related family members of 5$\mathrm{HT}_{2 \mathrm{~B}}$, these compounds also exhibited reasonably good selectivity. For example, compound 15 , bound to the $5-\mathrm{HT}_{2 \mathrm{~B}}$, $5-\mathrm{HT}_{2 \mathrm{~A}}$ and $5-\mathrm{HT}_{2 \mathrm{C}}$ with $K_{\mathrm{i}}$ values of $6.2,211$, and $156 \mathrm{nM}$, respectively.

Currently, only crystal structures of $5-\mathrm{HT}_{2 \mathrm{~B}}$ and $5-\mathrm{HT}_{1 \mathrm{~B}}$ receptors are determined in the $5 \mathrm{HT}$ receptor family. ${ }^{41}$ Structural comparison suggests that most of their binding-site residues are conserved, with the exception of residue 6.55 (Figure 5A). Substitution of $\mathrm{Asn}^{6.55}$ for $\mathrm{Ser}^{6.55}$ in the $5-\mathrm{HT}_{1 \mathrm{~B}}$ receptor abolishes the hydrogen bond interaction with our identified compounds, which should result in decreased binding affinity. On the basis of the sequence alignment of the 5-HTRs, three additional residues located in the ECL II region of 5$\mathrm{HT}_{2 \mathrm{~B}}$ are unique to the $5-\mathrm{HT}_{2 \mathrm{~B}}$ receptor (Figure $5 \mathrm{~B}$ ). These three additional residues form a helix turn and elevate the ECL II to an upper position, which facilitate the formation of an adjacent binding site in $5-\mathrm{HT}_{2 \mathrm{~B}}$ receptor, consisting of 
Table 1. Validation of the Predicted Binding Mode ${ }^{a}$

\begin{tabular}{|c|c|c|c|}
\hline No. & Structure & Inhibition (\%) at $1 \mu \mathrm{M}$ & $\mathrm{IC}_{50}(\mathrm{nM})$ \\
\hline 9 & & $107.2 \pm 0.6$ & 27.3 \\
\hline 11 & & $50.4 \pm 2.1$ & N.D. \\
\hline 12 & & $-11.6 \pm 4.5$ & N.D. \\
\hline 13 & & $107.8 \pm 0.0$ & 49.4 \\
\hline 14 & & $91.8 \pm 0.4$ & 284.5 \\
\hline 15 & & $97.4 \pm 2.2$ & 33.4 \\
\hline 1 & & $75.9 \pm 11.5$ & 327.6 \\
\hline 16 & & $84.6 \pm 1.2$ & 280.0 \\
\hline 5 & & $63.0 \pm 15.0$ & 1056.0 \\
\hline
\end{tabular}

${ }^{a}$ N.D. means not determined.

hydrophobic residues $\operatorname{Trp}^{3.28}, \mathrm{Leu}^{3.29}, \mathrm{Val}^{7.39}, \mathrm{Val} 208$, and Leu209 in ECL II. This hydrophobic site may accommodate the cyclohexene group and contribute to the selectivity of this type of compounds (Figure $5 \mathrm{~A}$ ). For the $5-\mathrm{HT}_{1 \mathrm{~B}}$ receptor, only two additional residues are located in the ECL II region and no helix turn is formed. Thus, the cyclohexene group of our compounds may not be accommodated into the reduced pocket created by this short loop region. This supposition is consistent with what is known about other aminergic GPCRs with solved crystal structures. The histamine $\mathrm{H}_{1}$ and $\mathrm{M}_{2}$ muscarinic acetylcholine receptors with three additional residues located in the ECL II region, exhibit similar conformations to the $5-\mathrm{HT}_{2 \mathrm{~B}}$ receptor. For the $\beta_{2}$-adrenergic and dopamine $\mathrm{D}_{3}$ receptors, however, only one or no residue located in this region, results in a closed conformation for ECL II and a reduced binding pocket (Figure S6, Supporting Information).

Inhibition of Visceral Hypersensitivity in an IBS Rat Model. We selected one of the most potent compounds from the in vitro binding and functional assays, compound 15 , and evaluated its in vivo therapeutic efficiency in an IBS rat model. Compared to its $5-\mathrm{HT}_{2 \mathrm{~B}}$ receptor antagonist activity, compound $\mathbf{1 5}$ exhibited relatively weak inhibitory activity against the hERG channel $\left(\mathrm{IC}_{50}>1 \mu \mathrm{M}\right.$, Figure S7, Supporting Information), and acute oral toxicity evaluation in rat showed no toxic response at a dose of $500 \mathrm{mg} / \mathrm{kg}$. The visceral sensitivity of rats was evaluated by abdominal withdrawal reflex (AWR). ${ }^{42}$ As shown in Figure $6 \mathrm{~A}$ and $6 \mathrm{~B}$, the recorded pain 
Table 2. SAR of the R Substituent ${ }^{a}$<smiles>[R][14c]1[14cH][14cH][14cH][14c](NC2=NC(N)=NC3(CCCCC3)N2)[14cH]1</smiles>

$\begin{array}{lccc}\text { no. } & \mathrm{R} & \text { inhibition }(\%) \text { at } 1 \mu \mathrm{M} & \mathrm{IC}_{50}(\mathrm{nM}) \\ \mathbf{1 7} & \mathrm{H} & -11.1 \pm 3.2 & \text { N.D. } \\ \mathbf{1 8} & 2-\mathrm{Me} & 39.9 \pm 3.4 & \text { N.D. } \\ \mathbf{1 9} & 2-\mathrm{OMe} & 20.7 \pm 3.6 & \text { N.D. } \\ \mathbf{1 5} & 3-\mathrm{Br} & 97.4 \pm 2.2 & 33.4 \\ \mathbf{1 6} & \text { 3-OMe } & 84.6 \pm 1.2 & 280.0 \\ \mathbf{9} & \text { 3-COOEt } & 107.2 \pm 0.6 & 27.3 \\ \mathbf{2 0} & \text { 3-COOH } & 4.4 \pm 3.3 & \text { N.D. } \\ \mathbf{2 1} & \text { 3-CO-n-Pr } & 106.0 \pm 0.8 & 35.8 \\ \mathbf{2 2} & \text { 3-CONHEt } & 95.5 \pm 4.8 & 104.0 \\ \mathbf{2 3} & \text { 3-COO-n-Pr } & 110.5 \pm 2.7 & 18.1 \\ \mathbf{2 4} & \text { 3-CO-c-Pr } & 4.0 \pm 1.1 & \text { N.D. } \\ \mathbf{2 5} & \text { 3-CON(Et })_{2} & 40.7 \pm 1.2 & \text { N.D. } \\ \mathbf{2 6} & \text { 4-Me } & 50.2 \pm 8.0 & 485.9 \\ \mathbf{2 7} & 4-\mathrm{Cl} & 57.1 \pm 5.4 & 531.0 \\ \mathbf{2 8} & \text { 4-N }(\mathrm{Me})_{2} & 17.6 \pm 0.4 & \text { N.D. }\end{array}$

${ }^{a}$ N.D. means not determined.

thresholds significantly decreased in IBS rats compared with control rats (score $3: 32 \mathrm{mmHg}$ vs $57 \mathrm{mmHg}, P<0.001$; score $4: 57 \mathrm{mmHg}$ vs $82 \mathrm{mmHg}, P<0.001)$. However, oral administration of compound $\mathbf{1 5}$ at $30 \mathrm{mg} / \mathrm{kg}$ produced a significant attenuation in visceral hypersensitivity $(68 \%$ inhibition for score 3, $P<0.001$ and $63 \%$ inhibition for score $4, P<0.01)$. The mRNA expression level of the $5-\mathrm{HT}_{2 \mathrm{~B}}$ receptor was relatively higher for the IBS rats, in both distal and proximal colons (Figure 6C), further indicating that blocking the $5-\mathrm{HT}_{2 \mathrm{~B}}$ receptor may contribute to the inhibition of visceral hypersensitivity in IBS rats.

\section{DISCUSSION AND CONCLUSION}

The great progress in the determination GPCR structures has inspired a surge in structure-based ligand discovery efforts. Previous docking studies have indicated the functional fidelity of the docking screen hits to the conformation of the GPCR targets. The activity of the hits has recapitulated the activity of the cocrystallized ligands. ${ }^{7}$ The only currently available $5-\mathrm{HT}_{2 \mathrm{~B}}$ structure is bound with a biased agonist; it is thought to exhibit conformational characteristics of both its active and inactive states. Our induced-fit models have incorporated the knowledge of antagonist bound induced-fit effects and yielded structures with inactive-like conformations as in other inactive aminergic GPCR structures (Figure 1B, Figure S1). Therefore, on this basis, we propose that our induced-fit models are likely more reasonable for $5-\mathrm{HT}_{2 \mathrm{~B}}$ antagonist screening than using

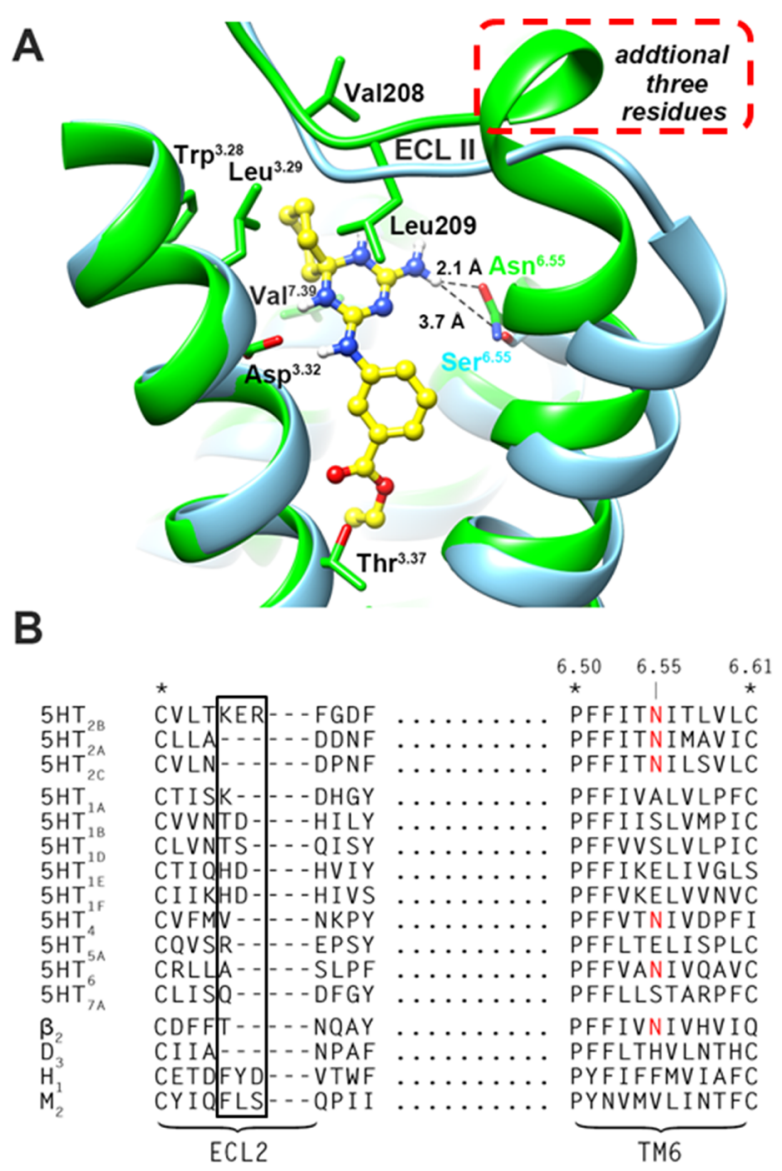

Figure 5. Potential ligand binding selectivity mechanism of the $5-\mathrm{HT}_{2 \mathrm{~B}}$ receptor. (A) Crystal structure comparsion between the $5-\mathrm{HT}_{2 \mathrm{~B}}$ (green, PDB ID: 4IB4) and 5- $\mathrm{HT}_{1 \mathrm{~B}}$ (cyan, PDB ID: 4IAR) receptors. (B) Sequence alignment of the ECL II and TM6 regions among 5HTRs and other GPCRs.

the crystal structure bound with a biased agonist. The retrospective docking screens of known $5-\mathrm{HT}_{2 \mathrm{~B}}$ antagonists indicated improved enrichment performance using our induced-fit models. Actually, the prospective docking screen against the crystal structure could not find any of our identified $5-\mathrm{HT}_{2 \mathrm{~B}}$ antagonists in the top 1000 compounds of scoring list (e.g., the rank of compound 9 is 3538); therefore, the optimization of the crystal conformation facilitated the successful identification of novel $5-\mathrm{HT}_{2 \mathrm{~B}}$ antagonists. Besides, we also tested the agonist activity for several of our compounds. None of them increased or decreased the basal-level activity of $5-\mathrm{HT}_{2 \mathrm{~B}}$ receptor at $1 \mu \mathrm{M}$. Thus, our compounds shall be pure antagonist, without possessing partial agonist or inverse agonist activity.

Further, the binding site also experiences subtle conformation changes when binding with different antagonists. Our MM-GB/SA calculation treated the binding site with flexible

Table 3. 5-HTRs Binding Profile Results $\left(K_{\mathrm{i}}, \mathrm{nM}\right)$

\begin{tabular}{|c|c|c|c|c|c|c|c|c|c|c|c|}
\hline no. & $5-\mathrm{HT}_{1 \mathrm{~A}}$ & $5-\mathrm{HT}_{1 \mathrm{~B}}$ & $5-\mathrm{HT}_{1 \mathrm{D}}$ & $5-\mathrm{HT}_{1 \mathrm{E}}$ & $5-\mathrm{HT}_{2 \mathrm{~A}}$ & $5-\mathrm{HT}_{2 \mathrm{~B}}$ & $5-\mathrm{HT}_{2 \mathrm{C}}$ & $5-\mathrm{HT}_{3}$ & $5-\mathrm{HT}_{5 \mathrm{~A}}$ & $5-\mathrm{HT}_{6}$ & $5-\mathrm{HT}_{7 \mathrm{~A}}$ \\
\hline 1 & 660 & 1531 & 2655 & $>10000$ & 783 & 20.5 & 265 & $>10000$ & 389 & 696 & 2083 \\
\hline 15 & 320 & $>10000$ & 2904 & $>10000$ & 211 & 6.2 & 156 & $>10000$ & 227 & 3031 & 401 \\
\hline 9 & 714 & $>10000$ & 8590 & $>10000$ & 174 & 7.2 & 851 & $>10000$ & 457 & 3587 & 472 \\
\hline 22 & 6764 & $>10000$ & $>10000$ & $>10000$ & 1313 & 27.5 & 1897 & $>10000$ & 994 & 5909 & 427 \\
\hline 14 & 116 & 9653 & 3830 & $>10000$ & 1541 & 38.5 & 1201 & $>10000$ & 595 & 4777 & 516 \\
\hline
\end{tabular}


A

The pressure threshold for CRD at Score 3

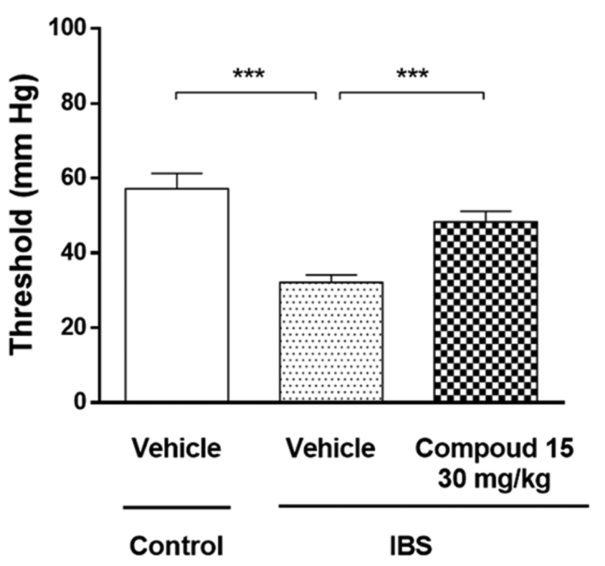

B

The pressure threshold for CRD at Score 4

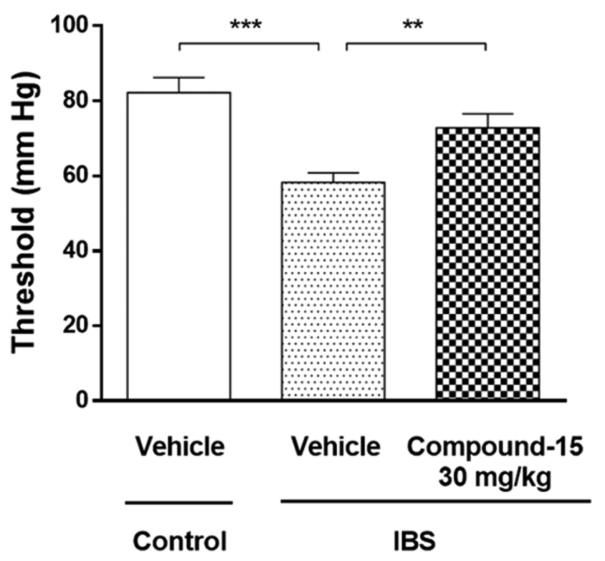

C

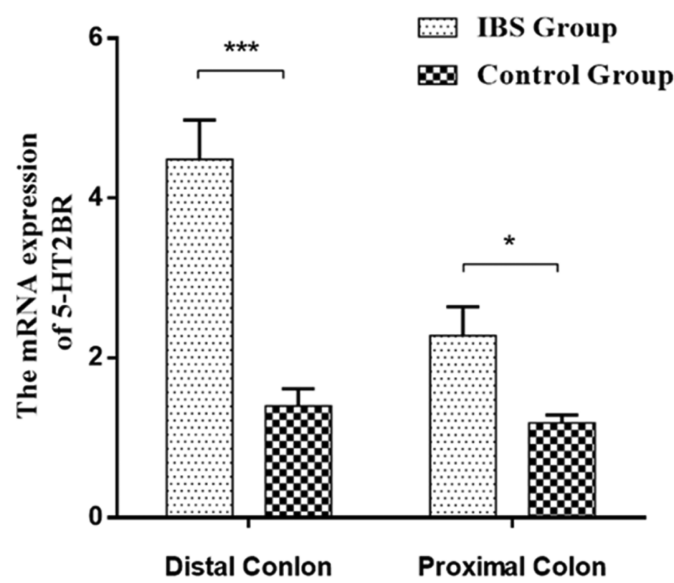

Figure 6. Inhibition of visceral hypersensitivity in IBS rat model. (A and B) Therapeutic effects of compound $\mathbf{1 5}$ in IBS rats. The pain threshold decreased in response to CRD (at score 3 and score 4). (C) Overexpression of mRNA for the $5-\mathrm{HT}_{2 \mathrm{~B}}$ receptor in IBS rat colons.

side-chain conformations and yielded improved correlation between the experimental $\mathrm{pIC}_{50}$ and computed $\Delta E$ compared with the rigid-receptor approximation, a result that emphasized the importance to incorporate binding-site flexibility into binding energy calculations.

As off-target interactions are responsible for the majority of adverse drug effects and failures in clinical trials, the identification of highly selective ligands is a critical aspect in modern drug discovery. Currently, very few 5-HTR ligands are subtype-selective, and the development of novel $5-\mathrm{HT}_{2 \mathrm{~B}}$ antagonists with better specificity is highly desirable. In this study, we identified a series of potent $5-\mathrm{HT}_{2 \mathrm{~B}}$ antagonists. These compounds represent a novel scaffold with distinct structural characteristics. Instead of containing the classical tertiary amine group, they utilize a protonated triazine ring to form a salt bridge interaction with the carboxylate group of conserved Asp ${ }^{3.32}$ and may also form additional hydrogen bonds with the Asn ${ }^{6.55}$ residue. Encouragingly, these compounds exhibited high selectivity for the $5-\mathrm{HT}_{2 \mathrm{~B}}$ receptor over other 5HTRs. In vivo assessment has further indicated that compound 15 could produce significant attenuation of visceral hypersensitivity in IBS rat models. Thus, this scaffold represents a new avenue for the development of novel and selective 5$\mathrm{HT}_{2 \mathrm{~B}}$ antagonists for the treatment of $5-\mathrm{HT}_{2 \mathrm{~B}}$ receptor-related disease.

\section{EXPERIMENTAL SECTION}

Binding Site Refinement and Analysis. Crystal structures of the histamine $\mathrm{H}_{1}$-doxepin complex (PDB ID: 3RZE) and the $\beta_{1^{-}}$ carvedilol complex (PDB ID: 4AMJ) were utilized to generate the initial binding modes of doxepin and carvedilol to the $5-\mathrm{HT}_{2 \mathrm{~B}}$ receptor. Considering the homology of the transmembrane regions, we assumed that both ligands would adopt a binding mode in the 5$\mathrm{HT}_{2 \mathrm{~B}}$ receptor similar to that in other GPCRs. Thus, we superimposed the ligand-bound GPCR structures on the $5-\mathrm{HT}_{2 \mathrm{~B}}$ structure (PDB ID: 4IB4) and extracted the coordinates of the ligands as their initial binding poses. Subsequently, the conformations of the binding-site residues in the $5-\mathrm{HT}_{2 \mathrm{~B}}$ receptor were sampled along with the placed ligand, using the Protein Local Optimization Program (PLOP) ${ }^{43-45}$ The ligand was minimized first, followed by side-chain sampling of the binding site residues within $10 \AA$ of the ligand. We implemented three rounds of such iterations to fully accommodate the ligand by sampling the surrounding residues.

To analyze the thermodynamic properties of the binding-site waters, we carried out $\mathrm{MD}$ simulations of the $5-\mathrm{HT}_{2 \mathrm{~B}}$ structure with the Gromacs v4.5.3 program, ${ }^{46}$ applying the AMBER99SB force field ${ }^{47}$ for the protein and the TIP3P water model. ${ }^{48}$ Water molecules and ligand in the crystal structure of the 5- $\mathrm{HT}_{2 \mathrm{~B}}$ receptor were removed. All calculations applied an atom-based truncation scheme that was updated heuristically with a list cutoff of $14 \AA$, a nonbond cutoff of 12 $\AA$, and the Lennard-Jones (LJ) smoothing function initiated at $10 \AA$. Long-range electrostatic interactions were computed using the Particle Mesh Ewald (PME) method. ${ }^{49}$ To equilibrate the solvent molecules around the solute, the system was minimized with 500 steps of steepest descent, followed by 200 ps of NVT MD simulation and a subsequent 200 ps of NPT simulation. The 12 ns of NVT MD production simulation was performed at $300 \mathrm{~K}$ via the v-rescale temperature coupling scheme. The LINCS algorithm ${ }^{50}$ was applied, with a time step of $2 \mathrm{fs}$, to constrain all bonds involving hydrogen atoms. All heavy atoms of the protein were harmonically restrained during the equilibration and production simulation with a force constant of $1000 \mathrm{~kJ} / \mathrm{mol} \cdot \mathrm{nm}^{2}$. The trajectories of the last $5 \mathrm{~ns}$ of the MD simulations were submitted as input to the Solvent Property Analysis (SPA $)^{35}$ program to compute the structural and energetic properties of the binding-site water molecules.

The induced-fit models were evaluated based on their ability to enrich known 5- $\mathrm{HT}_{2 \mathrm{~B}}$ ligands. In total, $2065-\mathrm{HT}_{2 \mathrm{~B}}$ antagonists were collected from the GLIDA database. ${ }^{51,52}$ We then further clustered these antagonists by their Bemis-Murcko atomic frameworks ${ }^{53}$ to obtain 84 structurally diverse ligands (Table S3, Supporting Information). For each ligand, 50 decoy compounds were generated based on the DUD-E protocol, ${ }^{54}$ leading finally to 4096 nonredundant decoys that were physically similar but topologically dissimilar to the annotated ligands (Figure S8, Supporting Information). Enrichment performance is one common metric used to measure docking performance; it represents the prioritization of true ligands among 
Scheme 1. General Procedure for Compound Synthesis ${ }^{a}$

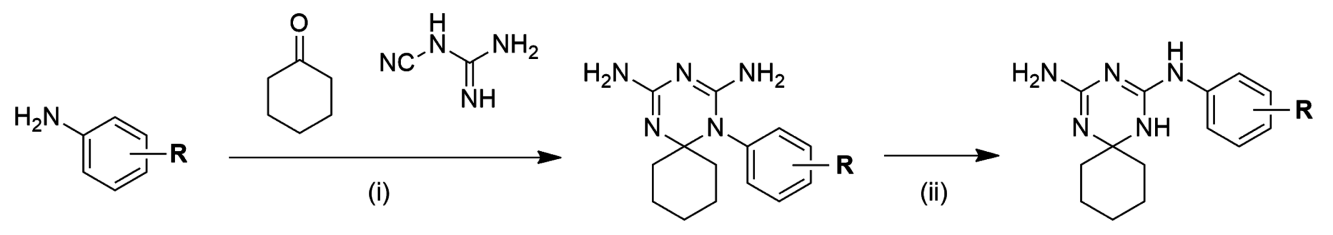

${ }^{a}$ Reaction conditions: (i) concd $\mathrm{HCl}$, EtOH, reflux; (ii) pyridine, EtOH, $120{ }^{\circ} \mathrm{C}$.

the top ranking hits of a docking-ordered library, which is calculated as $\mathrm{EF}_{\text {subset }}=\left(\right.$ ligands $\left.s_{\text {selected }} / N_{\text {subset }}\right) /\left(\right.$ ligand $\left.s_{\text {tota }} 1 / N_{\text {total }}\right){ }^{55}$

Structure-Based Hierarchical Virtual Screening. Molecular docking was performed with the DOCK $3.5 .54,{ }^{56,57}$ using the doxepininduced model as the receptor structure. Binding-site residues were identified within $12 \AA$ of doxepin. Then the solvent-accessible molecular surface was calculated with the $\mathrm{DMS}^{58}$ program using a probe radius of $1.4 \AA$. Receptor-derived matching spheres were generated with the SPHGEN program, ${ }^{59}$ and the ligand-derived spheres were generated from the positions of the heavy atoms of doxepin. Four sets of grids were generated: an excluded volume grid using DISMAP, ${ }^{60}$ a united atom AMBER-based van der Waals potential grid using CHEMGRID, ${ }^{60}$ an electrostatic potential grid using Delphi, ${ }^{61}$ and a solvent occlusion map using SOLVMAP. ${ }^{60}$ All of compounds in the library were prepared in the flexibase format with the latest version of the ZINC protocol. ${ }^{62,63}$ For sampling, the minimum number of graph matching nodes was set to 3 , and ligand overlap was set to 0.1 . Ligand conformations were scored on the basis of the total energy $\left(E_{\text {tot }}=E_{\text {vdw }}+E_{\text {ele }}-\Delta G_{\text {lig-solv }}\right)$ after 200 steps of rigid-body minimization, with initial translations of $0.2 \AA$ and initial rotations of $5^{\circ}$.

MM-GB/SA refinement and rescoring was performed using PLOP. Briefly, the docked ligand was subjected to the fully flexible minimization in the receptor and in the solvent with the all-atom OPLS force field and the Surface Generalized Born implicit solvent as described previously. ${ }^{36}$ The same protein structure used in the docking was used for rescoring. Hydrogen atoms were added in standard geometries as defined by the all-atom OPLS 2005 force field. ${ }^{64,65}$ The protein was kept rigid during protein-ligand complex minimization. The binding energy $\left(E_{\text {bind }}=E^{\mathrm{R} * \mathrm{~L}}-E^{\mathrm{L}}-E^{\mathrm{R}}\right)$ was calculated by subtracting the energies of the optimized free ligand in solution $\left(\mathrm{E}^{\mathrm{L}}\right)$ and the free protein in solution $\left(E^{\mathrm{R}}\right)$ from the optimized proteinligand complex's energy in solution $\left(E^{\mathrm{R} * \mathrm{~L}}\right)$. For the flexible rescoring procedure, the binding-site residues within $10 \AA$ of the ligand were subjected to side-chain prediction and energy minimization.

Chemistry. Our in-house screening compound library was constructed from the commercially available ChemDiv compound database (http://eu.chemdiv.com) based on maximizing structural diversity. ${ }^{37}$ Several analogues $(12,16-19$, and 26-28) for SAR studies were purchased from Vitas-M (http://www.vitasmlab.com), Chembridge (http://www.chembridge.com), and Enamine (http:// www.enamine.net), respectively. For each of these compounds, the vendor had verified the compound purity with liquid chromatography-mass spectrometry (LC-MS) and/or nuclear magnetic resonance (NMR) experiments. The ${ }^{1} \mathrm{H}$ NMR spectrum and the MS data for the initially identified active compound $\mathbf{9}$ are included in the Supporting Information.

The other compounds $(\mathbf{1 1}, \mathbf{1 3}-\mathbf{1 5}$, and 20-25) were prepared with reference to the general procedure described in Scheme $1 .{ }^{66}$ All solvents, chemicals, and reagents were obtained commercially and used without purification. The ${ }^{1} \mathrm{H}$ NMR spectra were obtained in $\mathrm{CDCl}_{3}, d_{6}$-DMSO, $\mathrm{CD}_{3} \mathrm{OD}$, or $d_{6}$-acetone at $25^{\circ} \mathrm{C}$ at $300 \mathrm{MHz}$ on an OXFORD instrument (Varian), with chemical shift $(\delta, \mathrm{ppm})$ reported relative to TMS as an internal standard. HPLC-MS chromatograms and mass spectra were obtained with a Shimadzu LC-MS-2020 system. The prep-HPLC instruments used included a Gilson GX-281(Gilson) and an Elite P230 Preparative Gradient System (Elite). Chiral PrepHPLC was performed with the Elite P230 Preparative Gradient System using Thar Prep- 80 and Thar SFC X-5 columns. The microwave instrument used was a CEM Discover SP. All tested compounds had a purity $>95 \%$.

Ethyl 3-((4-Amino-1,3,5-triazaspiro[5.5] undeca-2,4-dien-2yl)(methyl)amino)benzoate (11). Ethyl 3-aminobenzoate (4.1 g, $24.8 \mathrm{mmol})$ and di-tert-butyl dicarbonate $(8.1 \mathrm{~g}, 37.2 \mathrm{mmol})$ were dissolved in anhydrous THF $(60 \mathrm{~mL})$. Then $N$-ethyl- $N$-isopropylpropan-2-amine $(6.4 \mathrm{~g}, 49.6 \mathrm{mmol})$ was added. The reaction mixture was stirred at room temperature. After completion of the reaction, it was concentrated in vacuo, and the residue was extracted with ethyl acetate. The organic layer was concentrated and triturated with hexanes to provide ethyl 3-(tert-butoxycarbonylamino)benzoate as a white solid (5.6 g, $21.1 \mathrm{mmol}, 85 \%)$. MS $[\mathrm{M}+\mathrm{H}]^{+}$calculated for $\mathrm{C}_{14} \mathrm{H}_{20} \mathrm{NO}_{4}$ : 266.13, found: 266.10 .

Ethyl 3-(tert-butoxycarbonylamino)benzoate was dissolved in anhydrous THF $(20 \mathrm{~mL})$, and $\mathrm{NaH}(1.7 \mathrm{~g}, 42.2 \mathrm{mmol})$ was subsequently added under $\mathrm{N}_{2}$ atmosphere. The mixture was stirred at room temperature for $15 \mathrm{~min}$. $\mathrm{MeI}(2.0 \mathrm{~mL}, 31.7 \mathrm{mmol})$ was then added slowly in a dropwise manner. After completion, the reaction was quenched with saturated aqueous $\mathrm{NH}_{4} \mathrm{Cl}$ and extracted three times with ethyl acetate. The organic layers were combined and concentrated in vacuo to provide a residue; the residue was purified by column chromatography to give ethyl 3-(tert-butoxycarbonyl(methyl)amino)benzoate (2.4 g, 41\%).

Ethyl 3-(tert-butoxycarbonyl(methyl)amino)benzoate (2.4 g, 8.59 mmol) was dissolved in $\mathrm{HCl}(10 \mathrm{~mL}, 4 \mathrm{M})$ and THF $(10 \mathrm{~mL})$, and the mixture was refluxed overnight. It was then concentrated in vacuo, and the residue was purified by column chromatography to provide the ethyl 3-(methylamino)benzoate $(1.2 \mathrm{~g}, 80 \%)$. MS $[\mathrm{M}+\mathrm{H}]^{+}$calculated for $\mathrm{C}_{10} \mathrm{H}_{14} \mathrm{NO}_{2}: 180.09$, found: 180.10 .

A mixture of ethyl 3-(methylamino)benzoate $(606 \mathrm{mg}, 3.4 \mathrm{mmol})$, cyanoguanidine ( $313 \mathrm{mg}, 3.7 \mathrm{mmol})$, concentrated $\mathrm{HCl}(0.28 \mathrm{~mL}, 3.4$ $\mathrm{mmol})$, and cyclohexanone $(334 \mathrm{mg}, 3.4 \mathrm{mmol})$ in EtOH $(2 \mathrm{~mL})$ was refluxed for 2 days. The reaction mixture was neutralized with saturated $\mathrm{NaHCO}_{3}$ to $\mathrm{pH} 8$ and then extracted with $\mathrm{DCM}(50 \mathrm{~mL}$, three times). The organic layers were concentrated in vacuo to provide a crude product, which was purified by column chromatography to give the compound $11(28 \mathrm{mg}, 2.5 \%)$. ${ }^{1} \mathrm{H}$ NMR (400 MHz, DMSO$\left.d_{6}\right): \delta(\mathrm{ppm}) 8.77(\mathrm{~s}, 1 \mathrm{H}), 8.05-7.80(\mathrm{~m}, 3 \mathrm{H}), 7.63(\mathrm{~d}, J=5.1 \mathrm{~Hz}$, $2 \mathrm{H}), 7.00(\mathrm{~s}, 1 \mathrm{H}), 4.40-4.29(\mathrm{~m}, 2 \mathrm{H}), 3.38(\mathrm{~s}, 3 \mathrm{H}), 2.02-1.38(\mathrm{~m}$, $9 \mathrm{H}), 1.35-1.25(\mathrm{~m}, 4 \mathrm{H})$. MS $[\mathrm{M}+\mathrm{H}]^{+}$calculated for $\mathrm{C}_{18} \mathrm{H}_{26} \mathrm{~N}_{5} \mathrm{O}_{2}$ : 344.20, found: 344.20 .

Ethyl 3-(4-(Methylamino)-1,3,5-triazaspiro[5.5]undeca-2,4dien-2-ylamino)benzoate (13). Sodium dicyanoamide (5 g, 56.2 $\mathrm{mmol})$ and methylamine hydrochloride $(3.8 \mathrm{~g}, 56.2 \mathrm{mmol})$ were dissolved in $n$-butanol $(25 \mathrm{~mL})$ and $\mathrm{H}_{2} \mathrm{O}(10 \mathrm{~mL})$. The mixture was then refluxed. After completion of the reaction, the mixture was concentrated in vacuo and the residue was purified further by column chromatography to give 1-cyano-3-methylguanidine (1.7 g, 31\%). MS $[\mathrm{M}+\mathrm{H}]^{+}$calculated for $\mathrm{C}_{3} \mathrm{H}_{7} \mathrm{~N}_{4}$ : 99.06, found: 99.10.

A mixture of 1-cyano-3-methylguanidine (500 mg, $5.1 \mathrm{mmol})$, ethyl 3-aminobenzoate $(765 \mathrm{mg}, 4.63 \mathrm{mmol})$, and concentrated $\mathrm{HCl}(0.39$ $\mathrm{mL}, 4.63 \mathrm{mmol})$ in EtOH $(2 \mathrm{~mL})$ was refluxed for $6 \mathrm{~h}$. Then the ethyl 3-(3-(N-methylcarbamimidoyl)guanidino)benzoate was obtained by filtration (510 mg, 37\%). MS $[\mathrm{M}+\mathrm{H}]^{+}$calculated for $\mathrm{C}_{12} \mathrm{H}_{18} \mathrm{~N}_{5} \mathrm{O}_{2}$ : 264.14, found: 264.14 .

Ethyl 3-(3-(N-methylcarbamimidoyl)guanidino)benzoate $(510 \mathrm{mg}$, $1.7 \mathrm{mmol})$ in cyclohexanone $(15 \mathrm{~mL})$ and EtOH $(5 \mathrm{~mL})$ was refluxed overnight and then cooled to room temperature. Saturated aqueous $\mathrm{NaHCO}_{3}(25 \mathrm{~mL})$ was then added. The mixture was extracted with 
DCM (50 mL, three times) and washed with brine $(30 \mathrm{~mL})$. The organic layers were combined and concentrated in vacuo to afford a crude product, which was purified by column chromatography to provide the compound $13(230 \mathrm{mg}, 39 \%) .{ }^{1} \mathrm{H}$ NMR (400 MHz, DMSO- $\left.d_{6}\right): \delta(\mathrm{ppm}) 8.89(\mathrm{~s}, 1 \mathrm{H}), 7.96(\mathrm{~s}, 1 \mathrm{H}), 7.75(\mathrm{~d}, J=7.9 \mathrm{~Hz}$, $1 \mathrm{H}), 7.33(\mathrm{~d}, J=7.6 \mathrm{~Hz}, 1 \mathrm{H}), 7.22(\mathrm{t}, J=7.8 \mathrm{~Hz}, 1 \mathrm{H}), 6.41(\mathrm{~s}, 1 \mathrm{H})$, $5.76(\mathrm{~s}, 1 \mathrm{H}), 4.26(\mathrm{q}, J=7.1 \mathrm{~Hz}, 2 \mathrm{H}), 2.72(\mathrm{~d}, J=4.2 \mathrm{~Hz}, 3 \mathrm{H}), 1.73-$ $1.87(\mathrm{~m}, 2 \mathrm{H}), 1.67-1.23(\mathrm{~m}, 11 \mathrm{H}) . \mathrm{MS}[\mathrm{M}+\mathrm{H}]^{+}$calculated for $\mathrm{C}_{18} \mathrm{H}_{26} \mathrm{~N}_{5} \mathrm{O}_{2}: 344.20$, found: 344.20 .

Ethyl 3-(4-(Dimethylamino)-1,3,5-triazaspiro[5.5]undeca2,4-dien-2-ylamino)benzoate (14). Sodium dicyanoamide (5 g, $56.2 \mathrm{mmol}$ ) and dimethylamine hydrochloride $(4.58 \mathrm{~g}, 56.2 \mathrm{mmol})$ were dissolved in $n$-butanol and $\mathrm{H}_{2} \mathrm{O}$, and this mixture was then refluxed. After completion of the reaction, the mixture was concentrated in vacuo and the residue was purified further by column chromatography to obtain the product 2-cyano-1,1-dimethylguanidine (1.5 g, 24\%). MS $[\mathrm{M}+\mathrm{H}]^{+}$calculated for $\mathrm{C}_{4} \mathrm{H}_{9} \mathrm{~N}_{4}: 113.07$, found: 113.10 .

A mixture of 2-cyano-1,1-dimethylguanidine $(500 \mathrm{mg}, 4.46 \mathrm{mmol})$, ethyl 3-aminobenzoate $(670 \mathrm{mg}, 4.1 \mathrm{mmol})$, concentrated $\mathrm{HCl}(0.34$ $\mathrm{mL}, 4.1 \mathrm{mmol})$, and cyclohexanone (402 $\mathrm{mg}, 4.1 \mathrm{mmol})$ in EtOH (2 $\mathrm{mL}$ ) was refluxed. After completion of the reaction, it was cooled to room temperature. The reaction mixture was then neutralized with saturated $\mathrm{NaHCO}_{3}$ to $\mathrm{pH} 8$ and then extracted with $\mathrm{DCM}(50 \mathrm{~mL}$, three times). The organic layers were combined and concentrated in vacuo to afford a crude product, which was purified by column chromatography to give compound $14(60 \mathrm{mg}, 4 \%) .{ }^{1} \mathrm{H}$ NMR (400 MHz, DMSO- $\left.d_{6}\right): \delta(\mathrm{ppm}) 10.63(\mathrm{~s}, 1 \mathrm{H}), 9.14(\mathrm{~s}, 1 \mathrm{H}), 8.46(\mathrm{~s}, 1 \mathrm{H})$, $8.22(\mathrm{~s}, 1 \mathrm{H}), 7.69(\mathrm{~d}, J=7.6 \mathrm{~Hz}, 1 \mathrm{H}), 7.59(\mathrm{~d}, J=8.7 \mathrm{~Hz}, 1 \mathrm{H}), 7.50(\mathrm{t}$, $J=7.9 \mathrm{~Hz}, 1 \mathrm{H}), 4.31(\mathrm{q}, J=7.1 \mathrm{~Hz}, 2 \mathrm{H}), 3.30-2.97(\mathrm{~m}, 6 \mathrm{H}), 1.94-$ $1.61(\mathrm{~m}, 9 \mathrm{H}), 1.36-1.16(\mathrm{~m}, 4 \mathrm{H})$. MS $[\mathrm{M}+\mathrm{H}]^{+}$calculated for $\mathrm{C}_{19} \mathrm{H}_{28} \mathrm{~N}_{5} \mathrm{O}_{2}: 358.22$, found: 358.20 .

$N^{4}$-(3-Bromophenyl)-1,3,5-triazaspiro[5.5] undeca-1,3-diene2,4-diamine (15). A mixture of 3-bromobenzenamine (2 g, 11.6 mmol), cyanoguanidine (1.08 g, $12.8 \mathrm{mmol})$, concentrated $\mathrm{HCl}(1.0$ $\mathrm{mL}, 11.6 \mathrm{mmol})$, and cyclohexanone $(1.1 \mathrm{~g}, 11.6 \mathrm{mmol})$ in EtOH (2 $\mathrm{mL}$ ) was refluxed. After completion of the reaction, the solid was filtered to obtain 5-(3-bromophenyl)-1,3,5-triazaspiro[5.5] undeca-1,3diene-2,4-diamine (1.6 g, 41\%). MS $[\mathrm{M}+\mathrm{H}]^{+}$calculated for $\mathrm{C}_{14} \mathrm{H}_{19} \mathrm{BrN}_{5}$ : 336.07, found: 336.0 .

5-(3-Bromophenyl)-1,3,5-triazaspiro[5.5] undeca-1,3-diene-2,4-diamine was dissolved in pyridine $(2 \mathrm{~mL})$ and $\mathrm{EtOH}(3 \mathrm{~mL})$, and the mixture was heated to and held at $120{ }^{\circ} \mathrm{C}$ overnight. It was then concentrated in vacuo to dryness. After water $(10 \mathrm{~mL})$ was added, the mixture was stirred at room temperature for $30 \mathrm{~min}$. Then the solid was filtered and dried in vacuo to afford compound $15(310 \mathrm{mg}, 62 \%)$. ${ }^{1} \mathrm{H}$ NMR (400 MHz, DMSO- $\left.d_{6}\right): \delta(\mathrm{ppm}) 10.28(\mathrm{~s}, 1 \mathrm{H}), 8.91(\mathrm{~s}, 1 \mathrm{H})$, $8.58(\mathrm{~d}, J=4.2 \mathrm{~Hz}, 1 \mathrm{H}), 7.82-7.78(\mathrm{~m}, 1 \mathrm{H}), 7.58-7.49(\mathrm{~m}, 1 \mathrm{H}), 7.39$ $(\mathrm{dd}, J=7.6 \mathrm{~Hz}, J=5.7 \mathrm{~Hz}, 1 \mathrm{H}), 7.31-7.27(\mathrm{~m}, 2 \mathrm{H}), 1.88-1.16(\mathrm{~m}$, $10 \mathrm{H})$. MS $[\mathrm{M}+\mathrm{H}]^{+}$calculated for $\mathrm{C}_{14} \mathrm{H}_{19} \mathrm{BrN}_{5}: 336.07$, found: 336.0 .

3-(4-Amino-1,3,5-triazaspiro[5.5] undeca-2,4-dien-2ylamino)benzoic Acid (20). A solution of ethyl 3-(4-amino-1,3,5triazaspiro[5.5] undeca-2,4-dien-2-ylamino)benzoate $(25.0 \mathrm{mg}, 0.09$ $\mathrm{mmol})$ in $\mathrm{MeOH}(1.00 \mathrm{~mL})$ was added to $\mathrm{NaOH}(2.00 \mathrm{~mL})$. Then the reaction mixture was stirred at $30{ }^{\circ} \mathrm{C}$ overnight, diluted with water, and slowly acidified with trifluoroacetic acid to adjust the reaction mixture to $\mathrm{pH}<4$. The mixture was concentrated, and the resulting residue was then purified using reverse-phase chromatography to give a white solid $(3.0 \mathrm{mg}, 13 \%) .{ }^{1} \mathrm{H}$ NMR (400 MHz, DMSO- $\left.d_{6}\right): \delta$ (ppm) $1.37-1.70(\mathrm{~m}, 10 \mathrm{H}), 6.97-7.08(\mathrm{~m}, 1 \mathrm{H}), 7.44(\mathrm{t}, J=8.0 \mathrm{~Hz}$, $1 \mathrm{H}), 7.65-7.67(\mathrm{~m}, 1 \mathrm{H}), 7.82(\mathrm{~s}, 1 \mathrm{H}), 7.85-7.87(\mathrm{~m}, 1 \mathrm{H}), 8.57-8.71$ $(\mathrm{m}, 2 \mathrm{H}), 9.69-9.82(\mathrm{~m}, 1 \mathrm{H})$. MS $[\mathrm{M}+\mathrm{H}]^{+}$calculated for $\mathrm{C}_{15} \mathrm{H}_{20} \mathrm{~N}_{5} \mathrm{O}_{2}$ : 302.16, found: 302.30 .

1-(3-((4-Amino-1,3,5-triazaspiro[5.5] undeca-2,4-dien-2-yl)amino)phenyl)butan-1-one (21). A solution of 1-phenylbutan-1one $(2500 \mathrm{mg}, 16.9 \mathrm{mmol})$ was added to $\mathrm{HNO}_{3}(5 \mathrm{~mL})$ at $-5{ }^{\circ} \mathrm{C}$ dropwise in flask. The resulting suspension was stirred at $-5{ }^{\circ} \mathrm{C}$ for about $4 \mathrm{~h}$ and monitored by TLC until the starting materials were completely consumed. Ice- water was added to the reaction solution and filtered to give the crude product 1-(3-nitrophenyl)butan-1-one as a yellow solid, which was then used in the next step without further purification (900 mg, 28\%). MS $[\mathrm{M}+\mathrm{H}]^{+}$calculated for $\mathrm{C}_{10} \mathrm{H}_{12} \mathrm{NO}_{3}$ : 194.2, found: 194.2 .

A solution of 1-(3-nitrophenyl)butan-1-one $(900 \mathrm{mg}, 4.7 \mathrm{mmol})$ in EtOH $(50 \mathrm{~mL})$ was added to $\mathrm{Zn}$ powder $(0.6 \mathrm{~g}, 9.4 \mathrm{mmol})$ and concentrated $\mathrm{HCl}(1.8 \mathrm{~g}, 18.8 \mathrm{mmol})$ at $0{ }^{\circ} \mathrm{C}$. The resulting suspension was allowed to warm to room temperature and monitored by TLC until the starting materials were completely consumed. The reaction solution was filtered and the solvent was eliminated under reduced pressure to give the crude product, which was purified by chromatographic column to gain the desired product 1-(3aminophenyl)butan-1-one (450 mg, 59\%). MS $[\mathrm{M}+\mathrm{H}]^{+}$calculated for $\mathrm{C}_{10} \mathrm{H}_{14} \mathrm{NO}$ : 164.2 , found: 164.2 .

A solution of 1-(3-aminophenyl)butan-1-one $(450 \mathrm{mg}, 2.8 \mathrm{mmol})$ in $\mathrm{EtOH}(50 \mathrm{~mL})$ was added to cyanoguanidine $(235 \mathrm{mg}, 2.8 \mathrm{mmol})$ and concentrated $\mathrm{HCl}(2.8 \mathrm{~g}, 28 \mathrm{mmol})$ at room temperature. The resulting suspension was warmed to reflux overnight and monitored by TLC until the starting materials were completely consumed. The solvent was eliminated under reduced pressure to give the crude product 1-(3-(3-(carbamimidoyl)guanidino)phenyl)butan-1-one, which was used in the next step without further purification (180 $\mathrm{mg}, 26 \%)$. MS $[\mathrm{M}+\mathrm{H}]^{+}$calculated for $\mathrm{C}_{12} \mathrm{H}_{18} \mathrm{~N}_{5} \mathrm{O}: 248.3$, found: 248.3.

A solution of 1-(3-(3-(carbamimidoyl)guanidino)phenyl)butan-1one $(180 \mathrm{mg}, 0.7 \mathrm{mmol})$ in EtOH $(50 \mathrm{~mL})$ was added to cyclohexanone $(137 \mathrm{mg}, 1.4 \mathrm{mmol})$ and triethyl orthoformate (208 $\mathrm{mg}, 1.4 \mathrm{mmol}$ ) at $0{ }^{\circ} \mathrm{C}$. The resulting suspension was allowed to warm to room temperature overnight and monitored by TLC until the starting materials were completely consumed. The solvent was eliminated under reduced pressure to give the crude product 1-(3(2,4-diamino-1,3,5-triazaspiro[5.5] undeca-2,4-dien-1-yl)phenyl)butan1-one, which was used in the next step without further purification (120 mg, 51\%). MS $[\mathrm{M}+\mathrm{H}]^{+}$calculated for $\mathrm{C}_{18} \mathrm{H}_{26} \mathrm{~N}_{5} \mathrm{O}: 328.4$, found: 328.4 .

A solution of 1-(3-(2,4-diamino-1,3,5-triazaspiro[5.5] undeca-2,4dien-1-yl)phenyl)butan-1-one $(120 \mathrm{mg}, 0.37 \mathrm{mmol})$ in EtOH $(15 \mathrm{~mL})$ was added to pyridine $(315 \mathrm{mg}, 3.7 \mathrm{mmol})$ at room temperature. The resulting suspension was allowed to warm to reflux overnight and monitored by TLC until the starting materials were completely consumed. The solvent was eliminated under reduced pressure to give the crude product, which was washed with $\mathrm{MeOH}$ to afford the compound 21 (27 mg, 22\%). ${ }^{1} \mathrm{H}$ NMR (400 MHz, DMSO- $\left.d_{6}\right): \delta$ (ppm) $10.44(\mathrm{~s}, 1 \mathrm{H}), 9.08(\mathrm{~s}, 2 \mathrm{H}), 8.92(\mathrm{~s}, 1 \mathrm{H}), 8.53(\mathrm{t}, J=8.0 \mathrm{~Hz}$, $1 \mathrm{H}), 7.99-8.05(\mathrm{~m}, 2 \mathrm{H}), 7.86-7.97(\mathrm{~m}, 1 \mathrm{H}), 7.65-7.75(\mathrm{~m}, 1 \mathrm{H})$, $7.46-7.50(\mathrm{~m}, 1 \mathrm{H}), 3.44(\mathrm{q}, J=8.0 \mathrm{~Hz}, 1 \mathrm{H}), 3.00(\mathrm{t}, J=8.0 \mathrm{~Hz}, 2 \mathrm{H})$, $1.60-1.70(\mathrm{~m}, 9 \mathrm{H}), 1.28-1.51(\mathrm{~m}, 2 \mathrm{H}), 1.06(\mathrm{t}, J=8.0 \mathrm{~Hz}, 2 \mathrm{H}), 0.94$ $(\mathrm{t}, J=8.0 \mathrm{~Hz}, 2 \mathrm{H})$. MS $[\mathrm{M}+\mathrm{H}]^{+}$calculated for $\mathrm{C}_{18} \mathrm{H}_{26} \mathrm{~N}_{5} \mathrm{O}: 328.21$, found: 328.2 .

3-(4-Amino-1,3,5-triazaspiro[5.5] undeca-2,4-dien-2-ylamino)- $\mathrm{N}$-ethylbenzamide (22). A solution of 3 -aminobenzoic acid (4.4 $\mathrm{g}, 32.1 \mathrm{mmol})$ and di-tert-butyl dicarbonate $(10.5 \mathrm{~g}, 48.2 \mathrm{mmol})$ in anhydrous THF $(60 \mathrm{~mL})$ was added to $\mathrm{N}$-ethyl- $\mathrm{N}$-isopropylpropan-2amine $(8.3 \mathrm{~g}, 64.2 \mathrm{mmol})$. The reaction mixture was stirred at room temperature. After completion of the reaction, it was concentrated in vacuo and the residue was extracted with ethyl acetate. The organic layer was concentrated, and the residue was purified by column chromatography to provide 3-(tert-butoxycarbonylamino)benzoic acid $(6.2 \mathrm{~g}, 82 \%)$. MS $[\mathrm{M}-\mathrm{H}]^{-}$calculated for $\mathrm{C}_{12} \mathrm{H}_{14} \mathrm{NO}_{4}$ : 236.10, found: 236.10.

A mixture of 3-(tert-butoxycarbonylamino)benzoic acid ( $2 \mathrm{~g}, 8.43$ mmol), HATU (6.4 g, $16.9 \mathrm{mmol}$ ), and $\mathrm{N}$-ethyl- $\mathrm{N}$-isopropylpropan-2amine $(3.27 \mathrm{~g}, 25.3 \mathrm{mmol})$ was dissolved in DMF $(40 \mathrm{~mL})$, and then the mixture was stirred at room temperature for $30 \mathrm{~min}$. Then ethanamine hydrochloride $(2.1 \mathrm{~g}, 25.3 \mathrm{mmol})$ was added. After completion of the reaction, water was added and the mixture was extracted three times with EtOAc. The organic layer was concentrated to give the crude product tert-butyl 3-(ethylcarbamoyl)phenylcarbamate $(2.24 \mathrm{~g}, 100 \%)$ which was used without further purification. 
tert-Butyl 3-(ethylcarbamoyl)phenylcarbamate $(3.24 \mathrm{~g}, 12.3 \mathrm{mmol})$ was dissolved in dioxane $(40 \mathrm{~mL})$, and then concentrated $\mathrm{HCl}(10$ $\mathrm{mL}$ ) was added. The mixture was stirred at room temperature for $8 \mathrm{~h}$. After completion of the reaction, it was concentrated in vacuo and the residue was purified by column chromatography to give 3-amino- $\mathrm{N}$ ethylbenzamide $(1.4 \mathrm{~g}, 70 \%)$. MS $[\mathrm{M}+\mathrm{H}]^{+}$calculated for $\mathrm{C}_{9} \mathrm{H}_{13} \mathrm{~N}_{2} \mathrm{O}$ : 165.09, found: 165.10 .

A mixture of 3-amino- $N$-ethylbenzamide $(1 \mathrm{~g}, 6.1 \mathrm{mmol})$, cyanoguanidine $(563 \mathrm{mg}, 6.7 \mathrm{mmol})$, concentrated $\mathrm{HCl}(0.51 \mathrm{~mL}$, $6.1 \mathrm{mmol})$, and cyclohexanone $(599 \mathrm{mg}, 6.1 \mathrm{mmol})$ in EtOH $(2 \mathrm{~mL})$ was refluxed. After completion of the reaction, the solid was filtered to give the desired product 3-(2,4-diamino-1,3,5-triazaspiro[5.5] undeca2,4-dien-1-yl)- $\mathrm{N}$-ethylbenzamide (1.18 g, 59\%) as a white solid. MS $[\mathrm{M}+\mathrm{H}]^{+}$calculated for $\mathrm{C}_{17} \mathrm{H}_{25} \mathrm{~N}_{6} \mathrm{O}$ : 329.20 , found: 329.20 .

3-(2,4-Diamino-1,3,5-triazaspiro[5.5] undeca-2,4-dien-1-yl)- $N$-ethylbenzamide $(300 \mathrm{mg}, 0.91 \mathrm{mmol})$ was dissolved in pyridine $(3 \mathrm{~mL})$, the mixture was heated to $120^{\circ} \mathrm{C}$ overnight, and then it was concentrated in vacuo to give the crude product as a salt. Then the solid was neutralized by sat. $\mathrm{NaHCO}_{3}$ to $\mathrm{pH}=8$. The solid was filtered and dried in vacuo to give the compound $\mathbf{2 2}(232 \mathrm{mg}, 77 \%)$ as a pale pink solid. ${ }^{1} \mathrm{H}$ NMR (400 MHz, DMSO- $\left.d_{6}\right): \delta(\mathrm{ppm}) 10.17$ (s, 1H), 8.909.01(m, 2H), $8.48(\mathrm{t}, J=5.3 \mathrm{~Hz}, 1 \mathrm{H}), 7.76-7.81(\mathrm{~m}, 2 \mathrm{H}), 7.57(\mathrm{~d}, J=$ $7.7 \mathrm{~Hz}, 1 \mathrm{H}), 7.41(\mathrm{t}, J=7.8 \mathrm{~Hz}, 1 \mathrm{H}), 7.18(\mathrm{~s}, 1 \mathrm{H}), 3.33-3.24(\mathrm{~m}$, $2 \mathrm{H}), 1.89-1.25(\mathrm{~m}, 10 \mathrm{H}), 1.12(\mathrm{t}, J=7.2 \mathrm{~Hz}, 3 \mathrm{H}) . \mathrm{MS}[\mathrm{M}+\mathrm{H}]^{+}$ calculated for $\mathrm{C}_{17} \mathrm{H}_{25} \mathrm{~N}_{6} \mathrm{O}: 329.20$, found: 329.20 .

Propyl 3-(4-Amino-1,3,5-triazaspiro[5.5] undeca-2,4-dien-2ylamino)benzoate (23). 3-Aminobenzoic acid ( $2 \mathrm{~g}, 14.6 \mathrm{mmol})$ was dissolved in propan-1-ol $(20 \mathrm{~mL})$, concentrated sulfuric acid $(0.5$ $\mathrm{mL}$ ) was added, and the mixture was refluxed overnight. After completion of the reaction, it was concentrated in vacuo to obtain propyl 3-aminobenzoate $(2.4 \mathrm{~g}, 92 \%)$ and used in the next step without further purification. MS $[\mathrm{M}+\mathrm{H}]^{+}$calculated for $\mathrm{C}_{10} \mathrm{H}_{14} \mathrm{NO}_{2}$ : 180.09, found: 180.10 .

A mixture of propyl 3-aminobenzoate $(2 \mathrm{~g}, 11.2 \mathrm{mmol})$, cyanoguanidine ( $1 \mathrm{~g}, 12.3 \mathrm{mmol})$, concentrated $\mathrm{HCl}(0.93 \mathrm{~mL}, 11.2$ $\mathrm{mmol})$, and cyclohexanone $(1.1 \mathrm{~g}, 11.2 \mathrm{mmol})$ in propan-1-ol $(2 \mathrm{~mL})$ was refluxed. After completion of the reaction, the solid was filtered to provide propyl 3-(2,4-diamino-1,3,5-triazaspiro[5.5] undeca-2,4-dien-1yl)benzoate $(1.1 \mathrm{~g}, 29 \%)$. MS $[\mathrm{M}+\mathrm{H}]^{+}$calculated for $\mathrm{C}_{18} \mathrm{H}_{26} \mathrm{~N}_{5} \mathrm{O}_{2}$ : 344.20, found: 344.20 .

Propyl 3-(2,4-diamino-1,3,5-triazaspiro[5.5] undeca-2,4-dien-1-yl)benzoate $(500 \mathrm{mg}, 1.46 \mathrm{mmol})$ was dissolved in pyridine $(2 \mathrm{~mL})$ and propan-1-ol $(3 \mathrm{~mL})$, and then the mixture was heated to $120{ }^{\circ} \mathrm{C}$ overnight. After LC-MS showed that the reaction was completed, the mixture was concentrated in vacuo to give the crude product as a salt. Then the solid was neutralized by sat. $\mathrm{NaHCO} 3$ to $\mathrm{pH}=8$. The solid was filtered and dried in vacuo to give the desired product $(410 \mathrm{mg}$, 82\%). ${ }^{1} \mathrm{H}$ NMR (400 MHz, DMSO- $\left.d_{6}\right): \delta(\mathrm{ppm}) 10.33(\mathrm{~s}, 1 \mathrm{H}), 8.97$ (s, $2 \mathrm{H}), 8.06-8.02(\mathrm{~m}, 1 \mathrm{H}), 7.88(\mathrm{~s}, 1 \mathrm{H}), 7.70(\mathrm{~d}, J=7.8 \mathrm{~Hz}, 1 \mathrm{H})$, $7.49(\mathrm{t}, J=7.9 \mathrm{~Hz}, 1 \mathrm{H}), 7.22(\mathrm{~s}, 1 \mathrm{H}), 4.25(\mathrm{t}, J=6.6 \mathrm{~Hz}, 2 \mathrm{H}), 1.78-$ $1.66(\mathrm{~m}, 10 \mathrm{H}), 1.49-1.31(\mathrm{~m}, 2 \mathrm{H}), 0.98(\mathrm{t}, J=7.4 \mathrm{~Hz}, 3 \mathrm{H}) . \mathrm{MS}[\mathrm{M}+$ $\mathrm{H}]^{+}$calculated for $\mathrm{C}_{18} \mathrm{H}_{26} \mathrm{~N}_{5} \mathrm{O}_{2}: 344.20$, found: 344.20 .

(3-((4-Amino-1,3,5-triazaspiro[5.5] undeca-2,4-dien-2-yl)amino)phenyl)(cyclopropyl)methanone (24). A mixture of (3aminophenyl) (cyclopropyl)methanone (350 mg, $2.0 \mathrm{mmol}$ ), cyanoguanidine $(185 \mathrm{mg}, 2.2 \mathrm{mmol})$, concentrated $\mathrm{HCl}(0.21 \mathrm{~mL}$, $2.5 \mathrm{mmol})$, and cyclohexanone $(216 \mathrm{mg}, 2.2 \mathrm{mmol})$ in EtOH $(5 \mathrm{~mL})$ was refluxed. After the reaction was complete, the solid was filtered to obtain cyclopropyl(3-(2,4-diamino-1,3,5-triazaspiro[5.5] undeca-2,4dien-1-yl)phenyl)methanone $(160 \mathrm{mg}, 25 \%)$. MS $[\mathrm{M}+\mathrm{H}]^{+}$calculated for $\mathrm{C}_{18} \mathrm{H}_{23} \mathrm{~N}_{5} \mathrm{O}$ : 326.1 , found: 326.1 .

Cyclopropyl(3-(2,4-diamino-1,3,5-triazaspiro[5.5] undeca-2,4-dien1-yl)phenyl)methanone $(80 \mathrm{mg}, 0.25 \mathrm{mmol})$ was dissolved in pyridine $(1 \mathrm{~mL})$ and $\mathrm{EtOH}(1.5 \mathrm{~mL})$, and then the mixture was heated to 120 ${ }^{\circ} \mathrm{C}$ overnight. After the reaction was complete, the mixture was concentrated in vacuo, and water $(2 \mathrm{~mL})$ was added. The mixture was stirred at room temperature for $30 \mathrm{~min}$. Then the solid was filtered and dried in vacuo to afford the compound 24 (68 mg, 85\%). ${ }^{1} \mathrm{H}$ NMR $\left(400 \mathrm{MHz}, \mathrm{DMSO}-d_{6}\right): \delta(\mathrm{ppm}) 8.93(\mathrm{~s}, 1 \mathrm{H}), 8.19(\mathrm{~d}, J=7.7 \mathrm{~Hz}$, $1 \mathrm{H}), 7.95(\mathrm{~d}, J=1.6 \mathrm{~Hz}, 1 \mathrm{H}), 7.60-7.69(\mathrm{~m}, 3 \mathrm{H}), 7.38(\mathrm{~s}, 1 \mathrm{H}), 6.44$ $(\mathrm{s}, 1 \mathrm{H}), 2.93-3.10(\mathrm{~m}, 1 \mathrm{H}), 1.93(\mathrm{t}, J=12.0 \mathrm{~Hz}, 2 \mathrm{H}), 1.56-1.63(\mathrm{~m}$, $5 \mathrm{H}), 1.39-1.23(\mathrm{~m}, 2 \mathrm{H}), 1.14-0.88(\mathrm{~m}, 5 \mathrm{H}) . \mathrm{MS}[\mathrm{M}+\mathrm{H}]^{+}$ calculated for $\mathrm{C}_{18} \mathrm{H}_{23} \mathrm{~N}_{5} \mathrm{O}$ : 326.1, found: 326.1 .

3-(2,4-Diamino-1,3,5-triazaspiro[5.5] undeca-2,4-dien-1-yl)$\mathrm{N}, \mathrm{N}$-diethylbenzamide (25). 3-Aminobenzoic acid (4.4 g, 32.1 $\mathrm{mmol})$ and di-tert-butyl dicarbonate $(10.5 \mathrm{~g}, 48.2 \mathrm{mmol})$ were dissolved in anhydrous THF $(60 \mathrm{~mL})$. Then $N$-ethyl- $N$-isopropylpropan-2-amine $(8.3 \mathrm{~g}, 64.2 \mathrm{mmol})$ was added. The reaction mixture was stirred at room temperature. After completion of the reaction, it was concentrated in vacuo and the residue was extracted with ethyl acetate. The organic layer was concentrated, and the residue was purified by column chromatograph to provide 3-(tert-butoxycarbonylamino)benzoic acid $(6.2 \mathrm{~g}, 82 \%)$; MS $[\mathrm{M}-\mathrm{H}]^{-}$calculated for $\mathrm{C}_{12} \mathrm{H}_{14} \mathrm{NO}_{4}$ 236.10, found 236.10 .

A mixture of 3-(tert-butoxycarbonylamino)benzoic acid ( $2 \mathrm{~g}, 8.43$ mmol), HATU (6.4 g, $16.9 \mathrm{mmol}$ ), and $\mathrm{N}$-ethyl- $\mathrm{N}$-isopropylpropan-2amine $(3.27 \mathrm{~g}, 25.3 \mathrm{mmol})$ was dissolved in DMF $(40 \mathrm{~mL})$, and then the mixture was stirred at room temperature for $30 \mathrm{~min}$. Then diethanamine hydrochloride $(2.77 \mathrm{~g}, 25.3 \mathrm{mmol})$ was added. After completion of the reaction, water was added and the mixture was extracted with EtOAc for three times. The organic layer was concentrated to give tert-butyl 3-(ethylcarbamoyl)phenylcarbamate $(2.2 \mathrm{~g}, 89 \%)$ which was used in the next step without further purification.

tert-Butyl 3-(ethylcarbamoyl)phenylcarbamate $(2.2 \mathrm{~g}, 7.52 \mathrm{mmol})$ was dissolved in dioxane $(40 \mathrm{~mL})$, and then concentrated $\mathrm{HCl}(10$ $\mathrm{mL}$ ) was added. The mixture was stirred at room temperature for $8 \mathrm{~h}$. After completion of the reaction, it was concentrated in vacuo and the residue was purified by column chromatography (silica gel, PE:EA = $4: 1)$ to give 3-amino- $N, N$-diethylbenzamide $(1.45 \mathrm{~g}, 100 \%) ;{ }^{1} \mathrm{H}$ NMR $\left(400 \mathrm{MHz}, \mathrm{CDCl}_{3}\right) \delta(\mathrm{ppm}) 7.16(\mathrm{t}, J=7.7 \mathrm{~Hz}, 1 \mathrm{H}), 6.82-6.53(\mathrm{~m}$, $3 \mathrm{H}), 3.53(\mathrm{~m}, 2 \mathrm{H}), 3.28(\mathrm{~m}, 2 \mathrm{H}), 1.22(\mathrm{~m}, 6 \mathrm{H}) . \mathrm{MS}[\mathrm{M}+\mathrm{H}]^{+}$ calculated for $\mathrm{C}_{11} \mathrm{H}_{16} \mathrm{~N}_{2} \mathrm{O}: 193.13$, found: 193.20 .

A mixture of 3-amino- $\mathrm{N}, \mathrm{N}$-diethylbenzamide $(500 \mathrm{mg}, 2.6 \mathrm{mmol})$, cyanoguanidine $(241 \mathrm{mg}, 2.86 \mathrm{mmol})$, concentrated $\mathrm{HCl}(0.22 \mathrm{~mL}$, $2.6 \mathrm{mmol})$, and cyclohexanone $(255 \mathrm{mg}, 2.6 \mathrm{mmol})$ in EtOH $(2 \mathrm{~mL})$ was refluxed for $6 \mathrm{~h}$. LC-MS showed that two isomer products were formed. The desired product compound 25 was obtained by PrepHPLC (52 mg, 6\%). ${ }^{1} \mathrm{H}$ NMR (400 MHz, DMSO- $\left.d_{6}\right): \delta(\mathrm{ppm}) 10.24$ (s, $1 \mathrm{H}), 9.17(\mathrm{~s}, 1 \mathrm{H}), 8.83(\mathrm{~s}, 1 \mathrm{H}), 7.82(\mathrm{~s}, 1 \mathrm{H}), 7.71(\mathrm{~m}, 1 \mathrm{H}), 7.49-$ $7.35(\mathrm{~m}, 2 \mathrm{H}), 7.36(\mathrm{~s}, 1 \mathrm{H}), 7.05(\mathrm{~d}, J=7.4 \mathrm{~Hz}, 1 \mathrm{H}), 3.43(\mathrm{~m}, 2 \mathrm{H})$, $3.19(\mathrm{~m}, 2 \mathrm{H}), 1.33(\mathrm{~m}, 16 \mathrm{H})$. MS $[\mathrm{M}+\mathrm{H}]^{+}$calculated for $\mathrm{C}_{17} \mathrm{H}_{25} \mathrm{~N}_{6} \mathrm{O}: 357.23$, found: 357.20 .

Biological Assays. Detailed descriptions of cellular function assay, binding assay, and animal assay are included in the Supporting Information. Briefly, cellular function assays were performed with the $\mathrm{CHO}-\mathrm{K} 1 / 5-\mathrm{HT}_{2 \mathrm{~B}}$ cell line, using a calcium flux assay method. The binding assays were performed by staff at the National Institute of Mental Health's Psychoactive Drug Screening Program (NIMHPDSP), following the standard protocol. ${ }^{67}$ The radiolabeled reference compounds $\left(\left[{ }^{3} \mathrm{H}\right] 8-\mathrm{OH}-\mathrm{DPAT}\right.$ for $5-\mathrm{HT}_{1 \mathrm{~A}} ;\left[{ }^{3} \mathrm{H}\right] \mathrm{GR} 127543$ for 5$\mathrm{HT}_{1 \mathrm{~B}}$ and 5-HT $\mathrm{HD}_{1 \mathrm{D}} ;\left[{ }^{3} \mathrm{H}\right] 5-\mathrm{HT}$ for 5- $\mathrm{HT}_{1 \mathrm{E}} ;\left[{ }^{3} \mathrm{H}\right]$ ketanserin for 5- $\mathrm{HT}_{2 \mathrm{~A}}$; $\left[{ }^{3} \mathrm{H}\right] \mathrm{LSD}$ for $5-\mathrm{HT}_{2 \mathrm{~B}}$ and $5-\mathrm{HT}_{2 \mathrm{C}}, 5-\mathrm{HT}_{5 x}, 5-\mathrm{HT}_{6}$, and $5-\mathrm{HT}_{7}$; $\left[{ }^{3} \mathrm{H}\right] \mathrm{LY} 278584$ for $\left.5-\mathrm{HT}_{3}\right)$ were used in the $K_{\mathrm{i}}$ determination assays. The PDSP online data entry and analysis system calculates the variance of the quadruplicate measurements (for the total, nonspecific, and test compound binding values); variances greater than $20 \%$ are flagged for further inspection, and assays are repeated if necessary. The IBS rat models for the visceral hypersensitivity assays were induced by the injection of 2,4,6-trinitrobenzenesulfonic acid (TNBS) and then treated with chronic unpredictable mild stress (CUMS). ${ }^{68}$ Haematoxylin-eosin (HE) stains of the proximal and distal colon were compared to confirm the lack of histological changes in the IBS rat model (Figure S9, Supporting Information). Behavioral responses to colorectal distension (CRD) were used to assess visceral sensitivity by observing the AWR. The pain threshold to CRD was determined as the minimum pressure required to evoke AWR score 3 and AWR score 4. 


\section{ASSOCIATED CONTENT}

\section{S Supporting Information}

The Supporting Information is available free of charge on the ACS Publications website at DOI: 10.1021/acs.jmedchem.5b01631.

Additional figures and tables illustrating all computational and biological results, detailed experimental procedures, and ${ }^{1} \mathrm{H}$ NMR spectra and LC-MS spectra data of all synthesized compounds (PDF)

Table illustrating biological results (CSV)

\section{AUTHOR INFORMATION}

\section{Corresponding Authors}

*Tel, 86-10-80720645; fax, 86-10-80720813; e-mail, huangniu@nibs.ac.cn.

*Tel, 86-29-84771502; fax, 86-29-82539041; e-mail, kaicwu@ fmmu.edu.cn.

\section{Author Contributions}

${ }^{\#}$ These authors contributed equally to this work.

\section{Notes}

The authors declare no competing financial interest.

\section{ACKNOWLEDGMENTS}

Financial support from the Chinese Ministry of Science and Technology "973" Grant (2014CB849802) and the National Natural Science Foundation of China (81470862) (to N.H.) is gratefully acknowledged. Y.Z. was supported by the AstraZeneca Open Innovation Postdoctoral Research Fellowship, the China Postdoctoral Science Foundation (2015M570948), and the Beijing Postdoctoral Research Foundation (2015ZZ-118). X-P.H. was supported by the National Institute of Mental Health Psychoactive Drug Screening Program (NIMH-PDSP, HHSN-271-2013-00017-C) directed by Bryan L. Roth (MD, Ph.D.) at the University of North Carolina at Chapel Hill and Program Officer Jamie Driscoll at NIMH (Bethesda, MD). Computational support was provided by the Supercomputing Center of the Chinese Academy of Sciences (SCCAS). We also thank the Chemical Center at NIBS for providing the in-house screening compounds.

\section{ABBREVIATIONS USED}

PAH, pulmonary arterial hypertension; ECL, extracellular loop; TM, transmembrane; TNBS, 2,4,6-trinitrobenzenesulfonic acid; HE, haematoxylin-eosin; AWR, abdominal withdrawal reflex; $\mathrm{CRD}$, colorectal distension; CUMS, chronic unpredictable mild stress

\section{REFERENCES}

(1) Filmore, D. It's a GPCR world. Mod. Drug Discovery 2004, 7, 2428

(2) Kolb, P.; Rosenbaum, D. M.; Irwin, J. J.; Fung, J. J.; Kobilka, B. K.; Shoichet, B. K. Structure-based discovery of beta $a_{2}$-adrenergic receptor ligands. Proc. Natl. Acad. Sci. U. S. A. 2009, 106, 6843-6848.

(3) Carlsson, J.; Yoo, L.; Gao, Z. G.; Irwin, J. J.; Shoichet, B. K.; Jacobson, K. A. Structure-based discovery of $\mathrm{A}_{2 \mathrm{~A}}$ adenosine receptor ligands. J. Med. Chem. 2010, 53, 3748-3755.

(4) Carlsson, J.; Coleman, R. G.; Setola, V.; Irwin, J. J.; Fan, H.; Schlessinger, A.; Sali, A.; Roth, B. L.; Shoichet, B. K. Ligand discovery from a dopamine $\mathrm{D}_{3}$ receptor homology model and crystal structure. Nat. Chem. Biol. 2011, 7, 769-778.

(5) Mysinger, M. M.; Weiss, D. R.; Ziarek, J. J.; Gravel, S.; Doak, A. K.; Karpiak, J.; Heveker, N.; Shoichet, B. K.; Volkman, B. F. Structure- based ligand discovery for the protein-protein interface of chemokine receptor CXCR4. Proc. Natl. Acad. Sci. U. S. A. 2012, 109, 5517-5522.

(6) Kruse, A. C.; Weiss, D. R.; Rossi, M.; Hu, J.; Hu, K.; Eitel, K.; Gmeiner, P.; Wess, J.; Kobilka, B. K.; Shoichet, B. K. Muscarinic receptors as model targets and antitargets for structure-based ligand discovery. Mol. Pharmacol. 2013, 84, 528-540.

(7) Weiss, D. R.; Ahn, S.; Sassano, M. F.; Kleist, A.; Zhu, X.; Strachan, R.; Roth, B. L.; Lefkowitz, R. J.; Shoichet, B. K. Conformation guides molecular efficacy in docking screens of activated beta- 2 adrenergic $\mathrm{G}$ protein coupled receptor. ACS Chem. Biol. 2013, 8, 1018-1026.

(8) Rodríguez, D.; Brea, J.; Loza, M. I.; Carlsson, J. Structure-based discovery of selective serotonin $5-\mathrm{HT}_{1 \mathrm{~B}}$ receptor ligands. Structure 2014, 22, 1140-1151.

(9) Wacker, D.; Wang, C.; Katritch, V.; Han, G. W.; Huang, X. P.; Vardy, E.; McCorvy, J. D.; Jiang, Y.; Chu, M.; Siu, F. Y.; Liu, W.; Xu, H. E.; Cherezov, V.; Roth, B. L.; Stevens, R. C. Structural features for functional selectivity at serotonin receptors. Science 2013, 340, 615619.

(10) Liu, W.; Wacker, D.; Gati, C.; Han, G. W.; James, D.; Wang, D.; Nelson, G.; Weierstall, U.; Katritch, V.; Barty, A.; Zatsepin, N. A.; Li, D.; Messerschmidt, M.; Boutet, S.; Williams, G. J.; Koglin, J. E.; Seibert, M. M.; Wang, C.; Shah, S. T.; Basu, S.; Fromme, R.; Kupitz, C.; Rendek, K. N.; Grotjohann, I.; Fromme, P.; Kirian, R. A.; Beyerlein, K. R.; White, T. A.; Chapman, H. N.; Caffrey, M.; Spence, J. C.; Stevens, R. C.; Cherezov, V. Serial femtosecond crystallography of G protein-coupled receptors. Science 2013, 342, 1521-1524.

(11) Rothman, R. B.; Baumann, M. H.; Savage, J. E.; Rauser, L.; McBride, A.; Hufeisen, S. J.; Roth, B. L. Evidence for possible involvement of $5-\mathrm{HT}_{2 \mathrm{~B}}$ receptors in the cardiac valvulopathy associated with fenfluramine and other serotonergic medications. Circulation 2000, 102, 2836-2841.

(12) Hutcheson, J. D.; Setola, V.; Roth, B. L.; Merryman, W. D. Serotonin receptors and heart valve disease-it was meant $2 \mathrm{~B}$. Pharmacol. Ther. 2011, 132, 146-157.

(13) Brea, J.; Castro-Palomino, J.; Yeste, S.; Cubero, E.; Parraga, A.; Dominguez, E.; Loza, M. I. Emerging opportunities and concerns for drug discovery at serotonin $5-\mathrm{HT}_{2 \mathrm{~B}}$ receptors. Curr. Top. Med. Chem. 2010, 10, 493-503.

(14) Panconesi, A.; Sicuteri, R. Headache induced by serotonergic agonists-a key to the interpretation of migraine pathogenesis? Cephalalgia 1997, 17, 3-14.

(15) Mucke, H. MT-500 (POZEN). Curr. Opin. Invest. Drugs 2001, 2, 419-421.

(16) Borman, R. A.; Tilford, N. S.; Harmer, D. W.; Day, N.; Ellis, E. S.; Sheldrick, R. L.; Carey, J.; Coleman, R. A.; Baxter, G. S. 5-HT receptors play a key role in mediating the excitatory effects of 5-HT in human colon in vitro. Br. J. Pharmacol. 2002, 135, 1144-1151.

(17) Spiller, R. Serotonergic agents and the irritable bowel syndrome: what goes wrong? Curr. Opin. Pharmacol. 2008, 8, 709-714.

(18) Launay, J. M.; Herve, P.; Peoc'h, K.; Tournois, C.; Callebert, J.; Nebigil, C. G.; Etienne, N.; Drouet, L.; Humbert, M.; Simonneau, G.; Maroteaux, L. Function of the serotonin 5-hydroxytryptamine 2B receptor in pulmonary hypertension. Nat. Med. 2002, 8, 1129-1135.

(19) Porvasnik, S. L.; Germain, S.; Embury, J.; Gannon, K. S.; Jacques, V.; Murray, J.; Byrne, B. J.; Shacham, S.; Al-Mousily, F. PRX08066, a novel 5-hydroxytryptamine receptor $2 \mathrm{~B}$ antagonist, reduces monocrotaline-induced pulmonary arterial hypertension and right ventricular hypertrophy in rats. J. Pharmacol. Exp. Ther. 2010, 334, 364-372.

(20) Soares, R. L. Irritable bowel syndrome: A clinical review. World J. Gastroenterol. 2014, 20, 12144-12160.

(21) Occhipinti, K.; Smith, J. W. Irritable bowel syndrome: a review and update. Clin. Colon Rectal Surg. 2012, 25, 46-52.

(22) Ashburn, T. T.; Gupta, M. S. The IBS market. Nat. Rev. Drug Discovery 2006, 5, 99-100.

(23) Mullard, A. FDA approves two IBS drugs. Nat. Rev. Drug Discovery 2015, 14, 449. 
(24) Wouters, M. M.; Roeder, J. L.; Tharayil, V. S.; Stanich, J. E.; Strege, P. R.; Lei, S.; Bardsley, M. R.; Ordog, T.; Gibbons, S. J.; Farrugia, G. Protein kinase $\mathrm{C}_{\gamma}$ mediates regulation of proliferation by the serotonin 5-hydroxytryptamine receptor 2B. J. Biol. Chem. 2009, 284, 21177-21184.

(25) Chen, Y.; Li, Z.; Yang, Y.; Lin, L.; Zhang, H. Effect of 5- $\mathrm{HT}_{2 \mathrm{~B}}$ receptor on the pathogenetic mechanism of irritable bowel syndrome subgroups in rat models. Acta Univ. Med. Nanjing 2012, 32, 609-615.

(26) Bassil, A.; Taylor, C.; Bolton, V.; Gray, K.; Brown, J.; Cutler, L.; Summerfield, S.; Bruton, G.; Winchester, W.; Lee, K.; Sanger, G. J. Inhibition of colonic motility and defecation by RS-127445 suggests an involvement of the $5-\mathrm{HT}_{2 \mathrm{~B}}$ receptor in rodent large bowel physiology. Br. J. Pharmacol. 2009, 158, 252-258.

(27) O'mahony, S.; Bulmer, D.; Coelho, A.; Fitzgerald, P.; Bongiovanni, C.; Lee, K.; Winchester, W.; Dinan, T.; Cryan, J. 5$\mathrm{HT}_{2 \mathrm{~B}}$ receptors modulate visceral hypersensitivity in a stress-sensitive animal model of brain-gut axis dysfunction. Neurogastroenterol. Motil. 2010, 22, 573-e124.

(28) Ohashi-doi, K.; Himaki, D.; Nagao, K.; Kawai, M.; Gale, J.; Furness, J.; Kurebayashi, Y. A selective, high affinity 5- $\mathrm{HT}_{2 \mathrm{~B}}$ receptor antagonist inhibits visceral hypersensitivity in rats. Neurogastroenterol. Motil. 2010, 22, e69-e76.

(29) Takahashi, N.; Inagaki, K.; Taniguchi, K.; Sakaguchi, Y.; Kawamura, $\mathrm{K}$. The novel 5- $\mathrm{HT}_{2 \mathrm{~B}}$ receptor antagonist, RQ-00310941, attenuates visceral hypersensitivity and abnormal defecation in rat models. Gastroenterology 2011, 140, S-607.

(30) Poissonnet, G.; Parmentier, J. G.; Boutin, J. A.; Goldstein, S. The emergence of selective $5-\mathrm{HT}_{2 \mathrm{~B}}$ antagonists structures, activities and potential therapeutic applications. Mini-Rev. Med. Chem. 2004, 4, $325-330$.

(31) Lin, X.; Huang, X.-P.; Chen, G.; Whaley, R.; Peng, S.; Wang, Y.; Zhang, G.; Wang, S. X.; Wang, S.; Roth, B. L.; Huang, N. Life beyond kinases: Structure-based discovery of sorafenib as nanomolar antagonist of 5-HT receptors. J. Med. Chem. 2012, 55, 5749-5759.

(32) Cusack, B.; Nelson, A.; Richelson, E. Binding of antidepressants to human brain receptors: Focus on newer generation compounds. Psychopharmacology (Berl) 1994, 114, 559-565.

(33) Shimamura, T.; Shiroishi, M.; Weyand, S.; Tsujimoto, H.; Winter, G.; Katritch, V.; Abagyan, R.; Cherezov, V.; Liu, W.; Han, G. W.; Kobayashi, T.; Stevens, R. C.; Iwata, S. Structure of the human histamine $\mathrm{H}_{1}$ receptor complex with doxepin. Nature 2011, 475, 6570 .

(34) Warne, T.; Edwards, P. C.; Leslie, A. G.; Tate, C. G. Crystal structures of a stabilized beta ${ }_{1}$-adrenoceptor bound to the biased agonists bucindolol and carvedilol. Structure 2012, 20, 841-849.

(35) Sun, H.; Zhao, L.; Peng, S.; Huang, N. Incorporating replacement free energy of binding-site waters in molecular docking. Proteins: Struct., Funct., Genet. 2014, 82, 1765-1776.

(36) Huang, N.; Kalyanaraman, C.; Irwin, J. J.; Jacobson, M. P. Physics-based scoring of protein-ligand complexes: Enrichment of known inhibitors in large-scale virtual screening. J. Chem. Inf. Model. 2006, 46, 243-253.

(37) Cao, R.; Liu, M.; Yin, M.; Liu, Q.; Wang, Y.; Huang, N. Discovery of novel tubulin inhibitors via structure-based hierarchical virtual screening. J. Chem. Inf. Model. 2012, 52, 2730-2740.

(38) Keiser, M. J.; Roth, B. L.; Armbruster, B. N.; Ernsberger, P.; Irwin, J. J.; Shoichet, B. K. Relating protein pharmacology by ligand chemistry. Nat. Biotechnol. 2007, 25, 197-206.

(39) Yuthavong, Y.; Tarnchompoo, B.; Vilaivan, T.; Chitnumsub, P.; Kamchonwongpaisan, S.; Charman, S. A.; McLennan, D. N.; White, K. L.; Vivas, L.; Bongard, E.; et al. Malarial dihydrofolate reductase as a paradigm for drug development against a resistance-compromised target. Proc. Natl. Acad. Sci. U. S. A. 2012, 109, 16823-16828.

(40) Wan, X.; Zhang, W.; Li, L.; Xie, Y.; Li, W.; Huang, N. A new target for an old drug: Identifying mitoxantrone as a nanomolar inhibitor of PIM1 kinase via kinome-wide selectivity modeling. J. Med. Chem. 2013, 56, 2619-2629.

(41) McCorvy, J. D.; Roth, B. L. Structure and function of serotonin G protein-coupled receptors. Pharmacol. Ther. 2015, 150, 129-142.
(42) Al-Chaer, E. D.; Kawasaki, M.; Pasricha, P. J. A new model of chronic visceral hypersensitivity in adult rats induced by colon irritation during postnatal development. Gastroenterology 2000, 119, $1276-1285$.

(43) Jacobson, M. A.; Kaminski, G. A.; Friesner, G. A.; Rapp, C. S. Force field validation using protein side chain prediction. J. Phys. Chem. B 2002, 106, 11673-11680.

(44) Jacobson, M. P.; Pincus, D. L.; Rapp, C. S.; Day, T. J.; Honig, B.; Shaw, D. E.; Friesner, R. A. A hierarchical approach to all-atom protein loop prediction. Proteins: Struct., Funct., Genet. 2004, 55, 351-367.

(45) Li, X.; Jacobson, M. P.; Friesner, R. A. High-resolution prediction of protein helix positions and orientations. Proteins: Struct., Funct., Genet. 2004, 55, 368-382.

(46) Van Der Spoel, D.; Lindahl, E.; Hess, B.; Groenhof, G.; Mark, A. E.; Berendsen, H. J. GROMACS: fast, flexible, and free. J. Comput. Chem. 2005, 26, 1701-1718.

(47) Hornak, V.; Abel, R.; Okur, A.; Strockbine, B.; Roitberg, A.; Simmerling, C. Comparison of multiple Amber force fields and development of improved protein backbone parameters. Proteins: Struct., Funct., Genet. 2006, 65, 712-725.

(48) Jorgensen, W. L.; Chandrasekhar, J.; Madura, J. D.; Impey, R. W.; Klein, M. L. Comparison of simple potential functions for simulating liquid water. J. Chem. Phys. 1983, 79, 926-935.

(49) Sciortino, F.; Essmann, U.; Stanley, H. E.; Hemmati, M.; Shao, J.; Wolf, G. H.; Angell, C. A. Crystal stability limits at positive and negative pressures, and crystal-to-glass transitions. Phys. Rev. E: Stat. Phys., Plasmas, Fluids, Relat. Interdiscip. Top. 1995, 52, 6484-6491.

(50) Hess, B.; Bekker, H.; Berendsen, H. J. C.; Fraaije, J. LINCS: A linear constraint solver for molecular simulations. J. Comput. Chem. 1997, 18, 1463-1472.

(51) Okuno, Y.; Yang, J.; Taneishi, K.; Yabuuchi, H.; Tsujimoto, G. GLIDA: GPCR-ligand database for chemical genomic drug discovery. Nucleic Acids Res. 2006, 34, D673-D677.

(52) Okuno, Y.; Tamon, A.; Yabuuchi, H.; Niijima, S.; Minowa, Y.; Tonomura, K.; Kunimoto, R.; Feng, C. GLIDA: GPCR—ligand database for chemical genomics drug discovery-database and tools update. Nucleic Acids Res. 2008, 36, D907-D912.

(53) Bemis, G. W.; Murcko, M. A. The properties of known drugs. 1. Molecular frameworks. J. Med. Chem. 1996, 39, 2887-2893.

(54) Mysinger, M. M.; Carchia, M.; Irwin, J. J.; Shoichet, B. K. Directory of useful decoys, enhanced (DUD-E): Better ligands and decoys for better benchmarking. J. Med. Chem. 2012, 55, 6582-6594.

(55) Huang, N.; Shoichet, B. K.; Irwin, J. J. Benchmarking sets for molecular docking. J. Med. Chem. 2006, 49, 6789-6801.

(56) Wei, B. Q.; Baase, W. A.; Weaver, L. H.; Matthews, B. W.; Shoichet, B. K. A model binding site for testing scoring functions in molecular docking. J. Mol. Biol. 2002, 322, 339-355.

(57) Lorber, D. M.; Shoichet, B. K. Hierarchical docking of databases of multiple ligand conformations. Curr. Top. Med. Chem. 2005, 5, 739-749.

(58) Ferrin, T. E.; Huang, C. C.; Jarvis, L. E.; Langridge, R. The MIDAS display system. J. Mol. Graphics 1988, 6, 13-27.

(59) Kuntz, I. D.; Blaney, J. M.; Oatley, S. J.; Langridge, R.; Ferrin, T. E. A geometric approach to macromolecule-ligand interactions. J. Mol. Biol. 1982, 161, 269-288.

(60) Mysinger, M. M.; Shoichet, B. K. Rapid context-dependent ligand desolvation in molecular docking. J. Chem. Inf. Model. 2010, 50, $1561-1573$.

(61) Nicholls, A.; Honig, B. A rapid finite difference algorithm, utilizing successive over-relaxation to solve the Poisson-Boltzmann equation. J. Comput. Chem. 1991, 12, 435-445.

(62) Irwin, J. J.; Shoichet, B. K. ZINC-a free database of commercially available compounds for virtual screening. J. Chem. Inf. Model. 2005, 45, 177-182.

(63) Irwin, J. J.; Sterling, T.; Mysinger, M. M.; Bolstad, E. S.; Coleman, R. G. ZINC: A free tool to discover chemistry for biology. J. Chem. Inf. Model. 2012, 52, 1757-1768.

(64) Jorgensen, W. L.; Maxwell, D. S.; Tirado-Rives, J. Development and testing of the OPLS all-atom force field on conformational 
energetics and properties of organic liquids. J. Am. Chem. Soc. 1996, $118,11225-11236$.

(65) Kaminski, G. A.; Friesner, R. A.; Tirado-Rives, J.; Jorgensen, W. L. Evaluation and reparametrization of the OPLS-AA force field for proteins via comparison with accurate quantum chemical calculations on peptides. J. Phys. Chem. B 2001, 105, 6474-6487.

(66) Ma, X.; Poon, T. Y.; Wong, P. T.; Chui, W. K. Synthesis and in vitro evaluation of 2,4-diamino-1,3,5-triazine derivatives as neuronal voltage-gated sodium channel blockers. Bioorg. Med. Chem. Lett. 2009, 19, 5644-5647.

(67) Besnard, J.; Ruda, G. F.; Setola, V.; Abecassis, K.; Rodriguiz, R. M.; Huang, X.-P.; Norval, S.; Sassano, M. F.; Shin, A. I.; Webster, L. A.; Simeons, F. R. C.; Stojanovski, L.; Prat, A.; Seidah, N. G.; Constam, D. B.; Bickerton, G. R.; Read, K. D.; Wetsel, W. C.; Gilbert, I. H.; Roth, B. L.; Hopkins, A. L. Automated design of ligands to polypharmacological profiles. Nature 2012, 492, 215-220.

(68) Papp, M.; Moryl, E. Antidepressant activity of non-competitive and competitive NMDA receptor antagonists in a chronic mild stress model of depression. Eur. J. Pharmacol. 1994, 263, 1-7. 